University of Nebraska - Lincoln

DigitalCommons@University of Nebraska - Lincoln

\title{
Biogeochemical transformation of Fe minerals in a petroleum- contaminated aquifer
}

John M. Zachara

Pacific Northwest National Laboratory, john.zachara@pnl.gov

Ravi K. Kukkadapu

Pacific Northwest National Laboratory, ravi.kukkadapu@pnl.gov

Paul Gassman

Pacific Northwest National Laboratory, paul.gassman@pnl.gov

Alice Dohnalkova

Pacific Northwest National Laboratory, alice.dohnalkova@pnl.gov

James K. Fredrickson

Pacific Northwest National Laboratory, jim.fredrickson@pnl.gov

See next page for additional authors

Follow this and additional works at: https://digitalcommons.unl.edu/usdoepub

Part of the Bioresource and Agricultural Engineering Commons

Zachara, John M.; Kukkadapu, Ravi K.; Gassman, Paul; Dohnalkova, Alice; Fredrickson, James K.; and Anderson, Todd, "Biogeochemical transformation of Fe minerals in a petroleum-contaminated aquifer" (2004). US Department of Energy Publications. 254.

https://digitalcommons.unl.edu/usdoepub/254

This Article is brought to you for free and open access by the U.S. Department of Energy at DigitalCommons@University of Nebraska - Lincoln. It has been accepted for inclusion in US Department of Energy Publications by an authorized administrator of DigitalCommons@University of Nebraska - Lincoln. 


\section{Authors}

John M. Zachara, Ravi K. Kukkadapu, Paul Gassman, Alice Dohnalkova, James K. Fredrickson, and Todd Anderson 
doi:10.1016/j.gca.2003.09.022

\title{
Biogeochemical transformation of $\mathrm{Fe}$ minerals in a petroleum-contaminated aquifer
}

\author{
John M. Zachara, ${ }^{1, *}$ Ravi K. Kukkadapu, ${ }^{1}$ Paul L. Gassman, ${ }^{1}$ Alice Dohnalkova, ${ }^{1}$ \\ Jim K. Fredrickson, ${ }^{1}$ and Todd ANDERSON ${ }^{2}$ \\ ${ }^{1}$ Pacific Northwest National Laboratory, MSIN K8-96, P.O. Box 999, Richland, WA 99352, USA \\ ${ }^{2}$ University of Massachusetts, Amherst, MA, USA
}

(Received January 10, 2003; accepted in revised form September 19, 2003)

\begin{abstract}
The Bemidji aquifer in Minnesota, USA is a well-studied site of subsurface petroleum contamination. The site contains an anoxic groundwater plume where soluble petroleum constituents serve as an energy source for a region of methanogenesis near the source and bacterial Fe(III) reduction further down gradient. Methanogenesis apparently begins when bioavailable Fe(III) is exhausted within the sediment. Past studies indicate that Geobacter species and Geothrix fermentens-like organisms are the primary dissimilatory Fe-reducing bacteria at this site. The Fe mineralogy of the pristine aquifer sediments and samples from the methanogenic (source) and Fe(III) reducing zones were characterized in this study to identify microbiologic changes to $\mathrm{Fe}$ valence and mineral distribution, and to identify whether new biogenic mineral phases had formed. Methods applied included X-ray diffraction; X-ray fluorescence (XRF); and chemical extraction; optical, transmission, and scanning electron microscopy; and Mössbauer spectroscopy.

All of the sediments were low in total Fe content $(\approx 1 \%)$ and exhibited complex Fe-mineralogy. The bulk pristine sediment and its sand, silt, and clay-sized fractions were studied in detail. The pristine sediments contained $\mathrm{Fe}(\mathrm{II})$ and $\mathrm{Fe}(\mathrm{III})$ mineral phases. Ferrous iron represented approximately $50 \%$ of $\mathrm{Fe}_{\mathrm{TOT}}$. The relative $\mathrm{Fe}(\mathrm{II})$ concentration increased in the sand fraction, and its primary mineralogic residence was clinochlore with minor concentrations found as a ferroan calcite grain cement in carbonate lithic fragments. $\mathrm{Fe}(\mathrm{III})$ existed in silicates (epidote, clinochlore, muscovite) and $\mathrm{Fe}(\mathrm{III})$ oxides of detrital and authigenic origin. The detrital Fe(III) oxides included hematite and goethite in the form of mm-sized nodular concretions and smaller-sized dispersed crystallites, and euhedral magnetite grains. Authigenic Fe(III) oxides increased in concentration with decreasing particle size through the silt and clay fraction. Chemical extraction and Mössbauer analysis indicated that this was a ferrihydrite like-phase. Quantitative mineralogic and Fe(II/III) ratio comparisons between the pristine and contaminated sediments were not possible because of textural differences. However, comparisons between the texturally-similar source (where bioavailable Fe(III) had been exhausted) and $\mathrm{Fe}(\mathrm{III})$ reducing zone sediments (where bioavailable Fe(III) remained) indicated that dispersed detrital, crystalline Fe(III) oxides and a portion of the authigenic, poorly crystalline Fe(III) oxide fraction had been depleted from the source zone sediment by microbiologic activity. Little or no effect of microbiologic activity was observed on silicate Fe(III). The presence of residual "ferrihydrite" in the most bioreduced, anoxic plume sediment (source) implied that a portion of the authigenic Fe(III) oxides were biologically inaccessible in weathered, lithic fragment interiors. Little evidence was found for the modern biogenesis of authigenic ferrous-containing mineral phases, perhaps with the exception of thin siderite or ferroan calcite surface precipitates on carbonate lithic fragments within source zone sediments. Copyright $\odot 2004$ Elsevier Ltd
\end{abstract}

\section{INTRODUCTION}

The fate and transport of crude oil has been extensively studied in a shallow groundwater aquifer near Bemidji, Minnesota, USA. These studies have documented subsurface microbiologic processes that oxidize soluble crude-oil components and the terminal electron acceptors involved (Lovley et al., 1989; Anderson and Lovley, 1999), the nature and evolution of the subsurface microbiologic community under such conditions (Anderson et al., 1998; Rooney-Varga et al., 1999), and the associated biogeochemical changes to water composition and sediment chemistry (Baedecker et al., 1992, 1993; Bennett et al., 1993). While site specific in nature, these field studies have provided an understanding of coupled subsurface microbiologic and geochemical processes that have had broad applicability to other sites, even to the biostabilization of sol-

* Author to whom correspondence should be addressed (john. zachara@pnl.gov). uble, polyvalent radionuclides released from DOE weapons waste (NABIR Strategic Plan, http://www.lbl.gov/nabir/).

Three primary biogeochemical zones have been recognized within the contamination plume in the Bemidji aquifer (Baedecker et al., 1993; Bennett et al., 1993; Eganhouse et al., 1993). At the distal end of the plume, a zone exists with lowered dissolved $\mathrm{O}_{2}$ where aerobic, bacterial degradation of soluble hydrocarbons (e.g., low molecular weight saturated and alicyclic hydrocarbons) is occurring (Eganhouse et al., 1993). This aerobic respiration depletes dissolved $\mathrm{O}_{2}$ closer to the source allowing for the development of a zone where the bacterial oxidation of aromatic compounds is coupled to dissimilatory $\mathrm{Mn}(\mathrm{III} / \mathrm{IV}$ ) and $\mathrm{Fe}(\mathrm{III})$ reduction (Lovley et al., 1989; Eganhouse et al., 1993; Anderson and Lovley, 1999). A final anoxic zone exists most proximate to the source where methanogenesis is dominant. The shift from Mn and Fe respiration to methanogenesis occurs after bioavailable $\mathrm{Mn}(\mathrm{III} / \mathrm{IV})$ and $\mathrm{Fe}(\mathrm{III})$ has been depleted from the sediment (Anderson and Lovley, 1999). 
The dissimilatory bacterial iron reduction process, which is the subject of this paper, influences the aqueous geochemistry and mineralogy of the anoxic plume region. Aqueous $\mathrm{Fe}$ increases to millimolar concentrations in the region of active Fe(III) reduction (Baedecker et al., 1993; Bennett et al., 1993). Parallel decreases in the concentration of extractable sedimentary $\mathrm{Fe}$ (III) oxides result from the reductive dissolution process (Anderson and Lovley, 1999). Bioavailable Fe(III) is believed to exist in the sediment in the form of a poorly crystalline $\mathrm{Fe}$ (III) oxide such as ferrihydrite, but its precise nature is unknown. Mass balance geochemical calculations (Baedecker et al., 1993) suggest that siderite and ferroan calcite precipitation decreases down gradient $\mathrm{Fe}(\mathrm{II})$ concentrations within the anoxic zone. The formation of other authigenic ferrous-containing phases in the anoxic zone, including magnetite, has also been suggested based on mineralogic analyses of the sediments (Baedecker et al., 1992).

Pure cultures of dissimilatory iron reducing bacteria (DIRB) induce mineralogic transformation of $\mathrm{Fe}(\mathrm{III})$ oxides in the laboratory. Geobacter species, which are strict anaerobes, produce both fine-grained magnetite and siderite from ferrihydrite (Lovley, 1990; Mortimer and Coleman, 1997). Facultative Shewanella species may transform 2-line ferrihydrite to 6-line ferrihydrite, goethite, hematite, lepidocrocite, siderite, magnetite, vivianite, and green rust (Fredrickson et al., 1998; Zachara et al., 2002; Fredrickson et al., 2003; Kukkadapu et al., 2003). Some of these biomineralization products exhibit distinct morphology. Little is known about the biotransformation of ferrihydrite in the field, as its concentrations are typically low, and its poorly crystalline character complicates its tracking by techniques such as X-ray diffraction.

In this communication, we study sediments from pristine and contaminated (methanogenic and iron-reducing) zones of the Bemidji aquifer to provide insights on: i) the nature of the bioavailable $\mathrm{Fe}$ (III) fraction, ii.) changes in the mineralogy due to bacterial utilization of $\mathrm{Fe}(\mathrm{III})$ as an electron acceptor, and iii.) postreduction biogeochemical reactions of $\mathrm{Fe}(\mathrm{II})$ with the sedimentary matrix. These goals are accomplished through application of optical microscopy, X-ray diffraction, transmission and scanning electron microscopy with energy dispersive analyses (EDS), and Mössbauer spectroscopy. Our results both support and repudiate previous findings regarding the bacterial changes to the mineralogy of this site, and provide detailed insights on the coupling of microbiologic and geochemical processes in the field.

\section{EXPERIMENTAL METHODS}

\subsection{Site Characteristics}

Pristine and contaminated sediments were obtained from a shallow groundwater aquifer near Bemidji, Minnesota. A small area of the aquifer was contaminated by oil spillage in 1979. The site was extensively studied after the oil spill by the U.S. Geological Survey (Baedecker et al., 1993; Bennett et al., 1993; Eganhouse et al., 1993; Cozzarelli et al., 1994). The aquifer sediments are Pleistocene age glacial deposits (outwash primarily) resulting from Wisconsin glaciation. The mineralogy of the aquifer sediments reflects mixed provenance from carbonate, igneous, and metamorphic geologic terrains.

Four samples were obtained from the site in 2000 that were obtained by split-spoon coring: pristine aquifer sediment, and sediments from the anoxic contaminant plume [source area (methanogenic), mixed terminal acceptor (\#534), and Fe-reducing (\#531)]. The \#534 sediment is not discussed in this manuscript. The sediments were maintained in anoxic state after sampling and were stored in the form of a sediment/ groundwater slurry. Sample volumes and masses of the contaminated samples were limited and restricted certain types of analyses for these samples.

\subsection{Sediment Preparation}

The pristine sediment was wet sieved at $2.0 \mathrm{~mm}$ using deionized water. The coarse material $(>2.0 \mathrm{~mm})$ was dried at $70^{\circ} \mathrm{C}$ overnight. The $<2.0 \mathrm{~mm}$ fraction was sieved again at $53 \mu \mathrm{m}$. The volume of the $<53 \mu \mathrm{m}$ fraction was reduced to $250 \mathrm{~mL}$ by centrifugation. The suspension was equilibrated overnight and a final $\mathrm{pH}$ of 9.4 was recorded. This high $\mathrm{pH}$ indicated the presence of carbonate minerals in the sediments. The centrifugal separation of the $\leq 2 \mu \mathrm{m}$ and $2-53 \mu \mathrm{m}$ fractions was subsequently limited to three centrifugations to minimize carbonate dissolution.

The source area and $\mathrm{Fe}(\mathrm{III})$ reducing sediments were used withou size fractionation. Both of these sediments were $<2.0 \mathrm{~mm}$ in size. All three sediments and selected size $(53-250 \mu \mathrm{m} ; 250-2000 \mu \mathrm{m})$ and mineralogic fractions from the pristine sediment were analyzed by optical microscopy.

\subsection{Chemical Extractions}

Samples of the source area, $\mathrm{Fe}(\mathrm{III})$ reducing, and pristine sediments $(<2.0 \mathrm{~mm} ; 53-250 \mu \mathrm{m}, 2-53 \mu \mathrm{m}$, and $<2.0 \mu \mathrm{m})$ were extracted for $3.5 \mathrm{~h}$ with $0.2 \mathrm{~mol} / \mathrm{L}$ ammonium oxalate (at $\mathrm{pH} 3.0$ with $\mathrm{HCl}$; $\mathrm{AOx}$ ) in the dark to remove poorly crystalline Fe(III) oxides. The extract was separated by filtration $(0.2 \mu \mathrm{m})$ and was analyzed for $\mathrm{Fe}, \mathrm{Al}, \mathrm{Si}$, and Mn by ICP-MS. The extracts of the source area and Fe(III) reducing sediments were also analyzed for $\mathrm{Fe}(\mathrm{II})$ using the ferrozine assay (Stookey, 1970; Lovley and Phillips, 1986). The extracted sediment was thoroughly washed with anoxic $0.1 \mathrm{~mol} / \mathrm{L} \mathrm{NaClO}_{4}$ and $0.1 \mathrm{~mol} / \mathrm{L}$ $\mathrm{NaHCO}_{3}$, and then deoxygenated, deionized water to remove excess salt. The sediment was dried under anoxic atmosphere before analysis by Mössbauer spectroscopy.

The source area, $\mathrm{Fe}$ (III) reducing, and pristine sediments $(<2.0 \mathrm{~mm}$; 53-250 $\mu \mathrm{m}, 2-53 \mu \mathrm{m}$, and $<2.0 \mu \mathrm{m}$ ) were contacted with dithionitecitrate-bicarbonate (DCB) according to Mehra and Jackson (1960) to remove reducible crystalline and poorly crystalline Fe(III) oxides. The suspensions were placed on a tray shaker and continuously agitated for $24 \mathrm{~h}$ at room temperature. The supernatant was removed after centrifugation and the extraction repeated two more times. The three extracts and three washings with $0.1 \mathrm{~mol} / \mathrm{L} \mathrm{NaClO}_{4}$ were combined for analysis. A subsample of the extract was filtered through a $0.2 \mu \mathrm{m}$ syringe filter and analyzed for [Fe] using the ferrozine assay (Stookey, 1970; Lovley and Phillips, 1986). The extracted sediment was transferred to a vacuum flask using anoxic deionized water and rinsed under vacuum with deionized water to remove excess salt. The sediment was dried under an anoxic atmosphere for analysis by Mössbauer spectroscopy.

Both replicate and single samples were extracted with AOx and DCB depending on sample availability (Table 1). Replicates generally showed a range in value that was $<10 \%$ of the mean.

\subsection{X-ray Fluorescence Analysis (XRF)}

The elemental composition of the background and contaminated sediments was obtained by energy dispersive XRF spectroscopy (KEVEX 0810A system) utilizing the backscatter fundamental parameter approach. Sediments were pelletized from approximately $500 \mathrm{mg}$ of $<100$ mesh dry material into a $3 \mathrm{~cm}$ wafer. The analytical system was comprised of a water-cooled tungsten X-ray tube, sample chamber with multiple sample positions, a series of secondary targets (typically $\mathrm{Ti}, \mathrm{Cu}, \mathrm{Zr}, \mathrm{Mo}, \mathrm{Sn}$ and $\mathrm{Gd})$, a preamplifier, and a microprocessor. The $\mathrm{X}$-rays were detected by a cryogenically cooled solid-state lithium drifted silicon detector connected to a multi-channel analyzer, which provided counts per channel or peaks for subsequent data analysis. The method of peak analysis is described in Nielson (1978), and Nielson and Sanders (1982). The 1-sigma statistical variance of the element concentrations due to counting error $(\mathrm{Sc})$ was calculated from the following formula: 
Table 1. Distribution of Fe in Bemidji sediment.

\begin{tabular}{|c|c|c|c|c|c|c|}
\hline & $\begin{array}{c}\text { Pristine } \\
(<2.0 \mathrm{~mm})\end{array}$ & $\begin{array}{c}\text { Pristine } \\
(53-250 \mu \mathrm{m})\end{array}$ & $\begin{array}{c}\text { Pristine } \\
(2-53 \mu \mathrm{m})\end{array}$ & $\begin{array}{c}\text { Pristine } \\
(<2.0 \mu \mathrm{m})\end{array}$ & $\begin{array}{l}\text { Fe(III) reducing } \\
\text { sediment }\end{array}$ & Source \\
\hline Fe-total $^{\mathrm{a}}(\%)$ & $1.05( \pm 0.053)$ & $2.42( \pm 0.12)$ & $3.82( \pm 0.19)$ & $10.7( \pm 0.54)$ & $0.91( \pm 0.045)$ & $0.94( \pm 0.047)$ \\
\hline $\mathrm{Fe}(\mathrm{III})-\mathrm{AOx}(\mu \mathrm{mol} / \mathrm{g})$ & $12.0^{\mathrm{d}}$ & ND & $188^{\mathrm{d}}$ & $655^{\mathrm{e}}$ & $26^{\mathrm{d}}$ & $17.4^{\mathrm{e}}$ \\
\hline$\left(\%\right.$ of $\left.\mathrm{Fe}_{\mathrm{TOT}}\right)$ & 6.60 & & 27 & 33.6 & 15.7 & 10.2 \\
\hline $\mathrm{Fe}(\mathrm{III})-\mathrm{DCB}(\mu \mathrm{mol} / \mathrm{g})$ & $48.3^{\mathrm{d}}$ & ND & $304^{\mathrm{e}}$ & $1318^{\mathrm{e}}$ & $29.2^{\mathrm{d}}$ & $22.3^{\mathrm{e}}$ \\
\hline$\left(\%\right.$ of $\left.\mathrm{Fe}_{\mathrm{TOT}}\right)$ & 26.6 & & 43.7 & 67.7 & 17.6 & 13.0 \\
\hline P.C. Fe(III) oxide & 24.8 & & 61.8 & 49.6 & 89.0 & 78.0 \\
\hline $\mathrm{Fe}_{(\mathrm{s})}{ }^{\mathrm{c}}\left(\%\right.$ of $\left.\mathrm{Fe}_{\text {тот }}\right)$ & 73.4 & & 38.2 & 32.3 & 82.4 & 87.0 \\
\hline
\end{tabular}

${ }^{a}$ By XRF, variance due to counting error is noted

${ }^{\mathrm{b}}$ Poorly crystalline Fe(III) oxide as $\%$ of the extractable Fe(III) $\left[\mathrm{Fe}_{\mathrm{EXT}}\right]$ P.C. Fe(III)oxide $=[\mathrm{Fe}-\mathrm{AOx}(\mu \mathrm{mol} / \mathrm{g}) / \mathrm{Fe}-\mathrm{DCB}(\mu \mathrm{mol} / \mathrm{g})] \times 100$

c $\%$ of total $\mathrm{Fe}$ in silicates $\mathrm{Fe}_{(\mathrm{s})}=\mathrm{Fe}_{\mathrm{TOT}}-\mathrm{Fe}_{\mathrm{DCB}}$.

${ }^{\mathrm{d}}$ Average of replicate analyses.

e Single analysis.

$$
S c=\frac{S_{n} \cdot Y \cdot A_{o} \cdot P \cdot E}{T \cdot K}
$$

where

$S_{n}=$ standard error in peak area

$Y=$ a normalization factor to alter concentration unit

$A_{o}=$ self adsorption correction factor

$P=$ particle size correction factor

$E=$ the enhancement correction factor

$T=$ the analysis life-time

$K=$ the element calibration factor (x-ray intensity per unit element mass)

\subsection{Powder X-ray Diffraction (XRD) Analysis}

Analyses of the bulk pristine sediment and its various particle size and mineralogic isolates were performed with a Philips PW3040/00 X'Pert MPD system using a $\mathrm{Cu}$ anode. The routine operating power was $2000 \mathrm{~W}(40 \mathrm{kV}, 50 \mathrm{~mA})$. Powder samples were tightly packed into the well (1/4-inch diameter) of low-background quartz XRD slides for analysis. Peak identification on the diffractograms was performed using the JADE+, V5 (Materials Data Inc., Livermore, California) data analysis software package.

\subsection{Electron Microscopy (SEM/TEM) and Energy Dispersive Analyses (EDS)}

Specimens for TEM were prepared by applying the material onto a $\mathrm{Cu}$ grid with a formvar support film coated with carbon. Imaging and analyses were performed using a JEOL 2010 high resolution TEM equipped with $\mathrm{L} \mathrm{LaB}_{6}$ filament as an electron source operated at $200 \mathrm{kV}$ with nominal resolution of $1.8 \AA$. Images were digitally collected and analyzed using a Gatan Digital Micrograph. For elemental analyses, an Oxford Link ISIS X-ray EDS microanalysis system was used with a 650-nm diameter spot size. Emitted X-rays were detected by a $\mathrm{Si}(\mathrm{Li})$ detector with 136-eV energy resolution. Samples for SEM analyses were applied on carbon tape, sputter coated with carbon, and imaged in LEO 924 FE SEM coupled with Oxford ISIS EDS and Rontec elemental mapping system.

\subsection{Mössbauer Spectroscopy}

Mössbauer spectroscopy was used to study the valence distribution and structural environment of $\mathrm{Fe}$ in the sediments. Sediments and mineral isolates were mixed with petroleum jelly in a 0.5 -inch thick and 0.375 -inch $\mathrm{Cu}$ holder and sealed with clear scotch tape and an aluminized-Mylar film. The pristine sediments $(75-150 \mathrm{mg})$ were used in air-dried form. Samples from the contaminated plume regions were dried under anoxic conditions. We have used similar mounting procedures for green rust compounds (that react rapidly with oxygen), and have observed no oxidation (Kukkadapu et al., 2004). The sample volume was equivalent to $\sim 25 \%$ of that of the sample holder. Thick- ness corrections were not applied because of low absorber densities. Liquid nitrogen measurements were performed using a top-loading Janis exchange-gas cryostat. The temperature was continuously monitored with a Nichrome thermocouple. The temperature was adjusted and maintained $( \pm 0.5 \mathrm{~K})$ with a Lakeshore Model DRC-93CA temperature controller. The entire drive-source assembly was external to the cryostat and only the sample was cooled to liquid nitrogen temperature.

Spectra were collected using a ${ }^{57} \mathrm{Co} / \mathrm{Rh}$ single-line thin source, with an initial activity of $50 \mathrm{mCi}$. The velocity transducer (MVT-1000; WissEL) was operated in the constant-acceleration mode $(23 \mathrm{~Hz}, \pm 5$ or $\pm 15 \mathrm{~mm} / \mathrm{s}$ ). Data were acquired on 1024 channels and then folded with the Recoil program (University of Ottawa) to 512 channels to give a flat background and a zero-velocity position corresponding to the center shift (CS or $\delta$ ) of a metallic-Fe foil at room temperature. Calibration spectra were obtained with a $20-\mu \mathrm{m}$ thick $\alpha$-Fe foil (Amersham, England) placed in exactly the same position as the samples to minimize any error due to changes in geometry. The transmitted radiation was recorded with an $\mathrm{Ar}-\mathrm{Kr}$ proportional counter.

Mössbauer spectra were evaluated with the Recoil program using the Voigt-based hyperfine distribution method of Rancourt and Ping (1991). Only one Mössbauer spectrum was collected for each sample or sample treatment. The data analysis involved the fitting of the Mössbauer spectrum with a hypothesized model of the contributing Fe sites that were described as quadrupole splitting distribution sites (doublet) or hyperfine field distribution sites (sextets). Goodness of fit of the overall multiple-site model was described in terms $\chi^{2}$. Spectral areas, reported as percent of total, were computed for each of the contributing sites. Statistics were computed for these spectral areas that were dependent on the number of data points (that were the same for each sample), the number of Fe sites, and the number of parameters describing each site. The coefficients of variation for the spectral areas of the individual sites generally ranged between 2 and $5 \%$ of the fitted value. The spectral areas were equated with the mass percentage of the different components or sites given the assumption of a constant recoil factor.

\section{RESULTS}

\subsection{Optical Microscopy}

\subsubsection{Pristine sediment}

The pristine sediment exhibited a faint brown-red color. Optical examination of the 53-250 $\mu \mathrm{m}$ and 250-2000 $\mu \mathrm{m}$ fractions of the pristine sediment showed it to be mineralogically complex and heterogeneous. Quartz was the dominant mineral, with clear and milky varieties the most abundant, but with a fair amount of translucent rose quartz. There were 


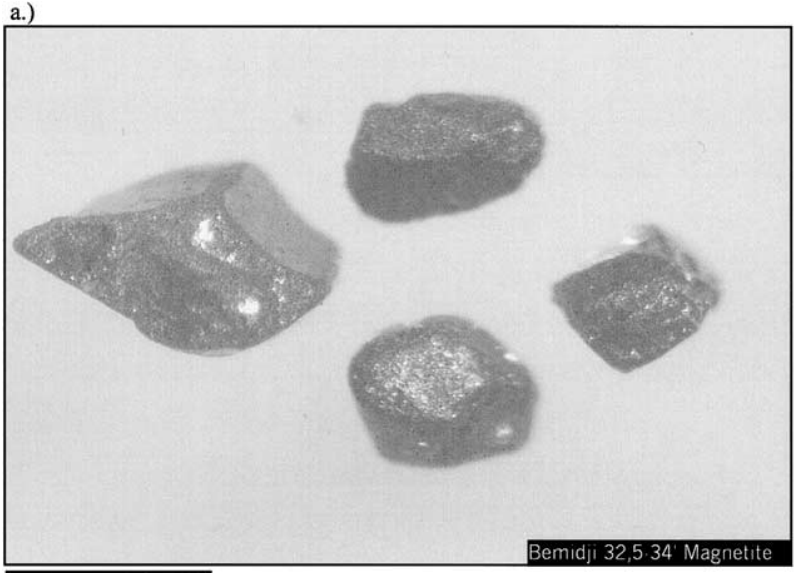

$500 \mu \mathrm{m}$

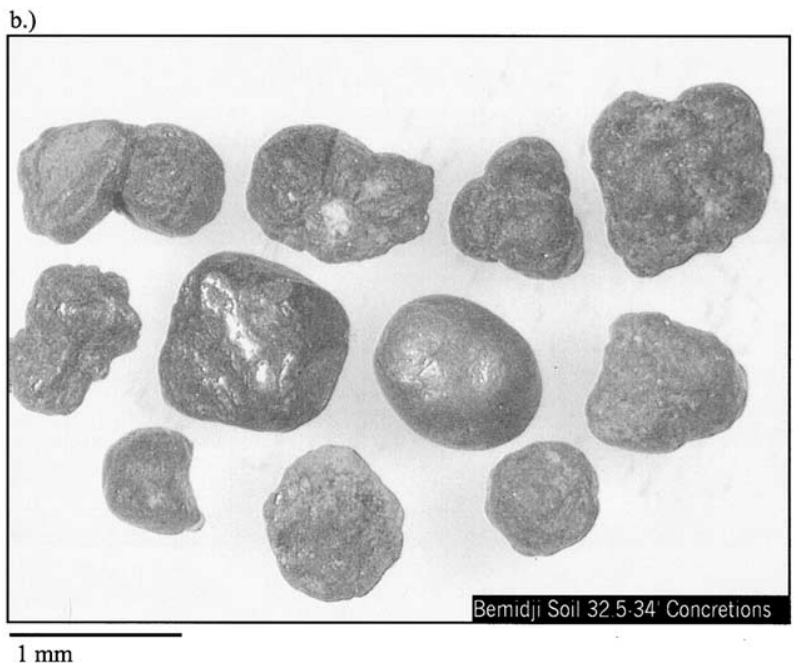

Fig. 1. Optical micrographs of mineral particles isolated from Bemidji pristine sediments. (a) Magnetite and (b) nodular concretions. Scale noted.

fragments of hornblende and pyroxenes, and grains of olivine (Mg rich-forsterite) and carbonates in the 53-250 $\mu \mathrm{m}$ fraction. Variably weathered phyllosilicates, including muscovite and chlorite were also evident. The 53-250 $\mu \mathrm{m}$ fraction contained many subrounded and subhedral grains of magnetite (Fig. 1a). These mineral isolates were confirmed as magnetite by X-ray diffraction and Mössbauer spectroscopy (data not shown). The magnetite grains were of a relatively uniform particle size.

Both the 53-250 $\mu \mathrm{m}$ and 250-2000 $\mu \mathrm{m}$ isolates contained curious, reddish-black, rounded grains with botryoidal habit that appeared to be iron containing, but were not magnetic (Fig. 1b). Their morphology and habit were insufficiently distinct to allow mineralogic identification, but individual grains were hand-picked for XRD and other analyses. There were also small, dispersed, subrounded grains of hematite in both particle size separates, and occasional polycrystalline aggregates that had yellow staining reminiscent of limonite. The hematite grains were finely crystalline and blood red, but not translucent. $\mathrm{Fe}(\mathrm{III})$ oxide also occurred as a coating on quartz fragments but these grains were not abundant.

\subsubsection{Contaminated sediments}

The source area and Fe(III)-reducing sediments exhibited a greenish-gray hue. Optical microscopy revealed that the distinctive red-black nodular concretions (Fig. 1b) were absent from the source area and Fe(III)-reducing sediments. Consistent with the noted color changes, Fe(III) oxide-stained rock fragments were not found in the source area or Fe(III)-reducing sediments as observed in the pristine sediment.

The Fe(III)-reducing sediment was a well-sorted fine quartz sand. There were abundant amphibole particles as found in the pristine sediment, but fewer rock fragments. Of these fragments, some had the appearance of being mafic. Very few grains were observed with $\mathrm{Fe}$ (III) oxide staining and these were primarily weathered potassium feldspars. Unlike the pristine sediment, quartz grains were generally free of Fe(III) oxide coatings, and were angular, subangular, and subrounded. Plagioclase and potassium feldspars were abundant in the $\mathrm{Fe}(\mathrm{III})$ reducing sediment. The potassium feldspar grains were smaller than those observed in the pristine sediment. The Fe(III) reducing sediment contained abundant magnetite. The magnetite grains were $10-20 \mu \mathrm{m}$ in size and were subhedral to anhedral in morphology.

The source area sediment, which had been oil contaminated, was washed free of oil residue using acetone. The acetonewashed material was extracted with DCB and AOx, and an untreated fraction was set aside for comparison. The three sediments appeared visually identical and were similar to the $\mathrm{Fe}(\mathrm{III})$ reducing sediment. Very few quartz grains had evidence of $\mathrm{Fe}$ (III) oxide coatings. Most of the quartz and feldspar grains were fractured to subrounded. Amphibole grains were slightly less abundant than in the Fe(III) reducing and pristine sediments. The source area material also had very few rock fragments, relative to the pristine sediment. Epidote grains and brilliant green amphibole grains were observed. The source material contained only a few magnetite grains, which were larger than those observed in the Fe(III) reducing sediment. No evidence was found for small, globular magnetite precipitates characteristic of biogenic formation (Sparks et al., 1990; Fredrickson et al., 1998), but the magnification power of the optical microscope was not high enough to differentiate such small particles. The source area sediment was compositionally and texturally similar to the pristine sediment except for the absence of the concretionary, nodular material.

\subsection{X-ray Diffraction Analyses}

The crystalline mineral composition of the pristine sediment varied with size fraction. Quartz and feldspar were dominant in the coarse fraction (Fig. 2), with minor calcite and dolomite being evident. Calcite and dolomite contents increased in the silt fraction (Fig. 2) and small peaks from clinochlore were evident. Muscovite was the dominant component of the clay fraction with minor amounts of clinochlore (Fig. 3). XRD analyses were not performed on the contaminated sediments because sample volumes were limited and oxidation during analysis was a concern.

The Fe(III) oxide coatings visible by optical microscopy were not evident by XRD. However, goethite and hematite, in association with chlorite and quartz, were observed as signifi- 


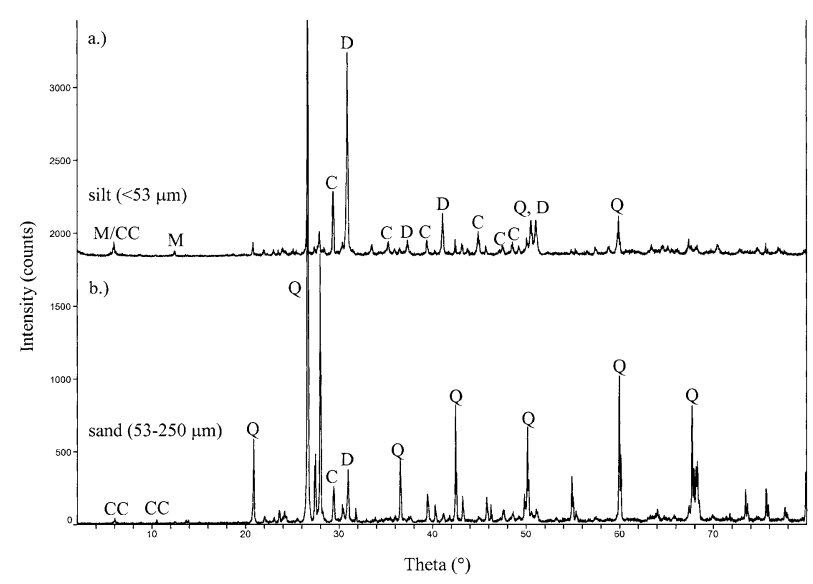

Fig. 2. Powder X-ray diffractograms of the (a) silt and (b) sand fractions of the pristine Bemidji aquifer sediment. $\mathrm{CC}=$ clinochlore; $\mathrm{M}$ $=$ muscovite $; \mathrm{C}=$ calcite $\mathrm{Q}=$ quartz; $\mathrm{D}=$ dolomite.

cant components of the nodular concretions shown in Figure $1 \mathrm{~b}$ (Fig. 4). Their nominal mass concentration in the $<2.0 \mathrm{~mm}$ pristine sediment appeared to be below the approximate XRD detection limit of $5 \%$.

\subsection{Chemical Analyses}

The total Fe in the pristine Bemidji sediment as determined by X-ray fluorescence measurement (XRF) was approximately $1 \%$ (see $<2.0 \mathrm{~mm}$ analyses, Table 1 ). Total-Fe increased with decreasing particle size through the silt and clay fractions (Table 1). A significant fraction of the total $\mathrm{Fe}$ in the pristine sediment was extracted as $\mathrm{Fe}(\mathrm{III})$ by AOx [poorly crystalline $\mathrm{Fe}(\mathrm{III})$ oxides] and DCB [total reducible Fe(III) oxides], Table 1. Poorly crystalline Fe(III) oxides represented a small fraction of total $\mathrm{Fe}$ in the $<2.0 \mathrm{~mm}$ sediment, but a larger fraction of the Fe was reducible in DCB indicating a significant crystalline $\mathrm{Fe}(\mathrm{III})$ oxide content. The different amounts of Fe(III) solubilized by the two extractants (AOx and DCB) indicated that the $\mathrm{Fe}(\mathrm{III})$ oxides in the pristine sediment exhibited a range in

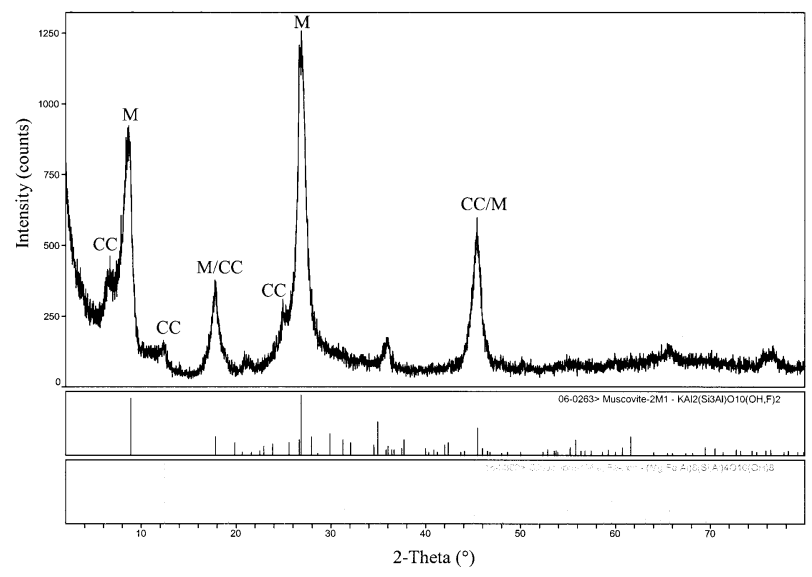

Fig. 3. Powder X-ray diffractogram of the clay-sized fraction of the pristine Bemidji aquifer sediment. $\mathrm{CC}=$ clinochlore; $\mathrm{M}=$ muscovite.

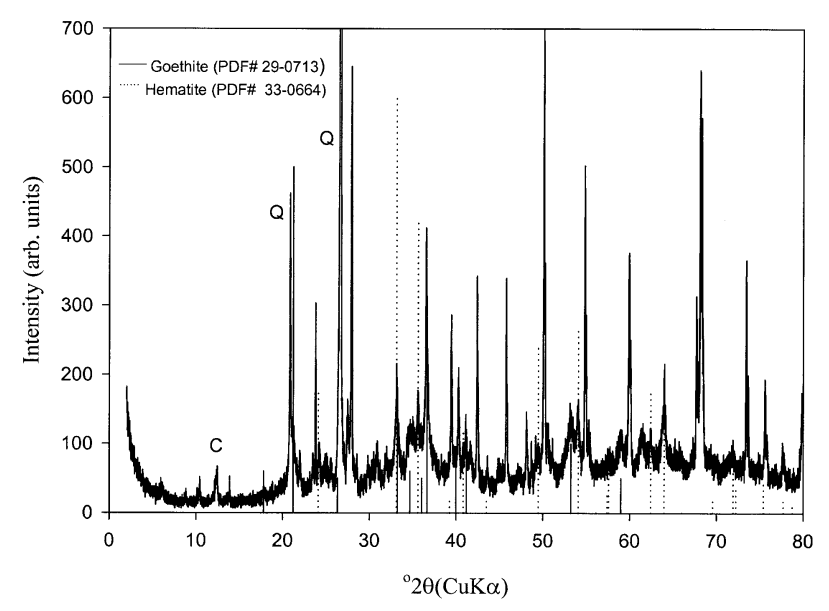

Fig. 4. Powder X-ray diffractogram of ground nodular concretions isolated from the coarse fraction of the pristine sediment. Goethite and hematite powder diffraction file (PDF) patterns were overlaid as a guide to the eye.

crystallinity. The Fe(III) oxides were not in high enough concentration, however, to be observed by XRD (Figs. 2 and 3).

Generally, the contaminated sediments had approximately $0.1 \%$ less total $\mathrm{Fe}$ (by XRF), and a smaller concentration of total reducible $\mathrm{Fe}(\mathrm{III})$ oxides than did the pristine sediment (Table 1). Moreover, the source area sediments, where methanogenesis predominates, had less extractable Fe(III) (both AOx and $\mathrm{DCB}$ ) than did sediment from the Fe(III)-reducing zone. The low AOx-extractable Fe(III) concentration in the pristine sediment $(12.0 \mu \mathrm{mol} / \mathrm{g})$ was difficult to rationalize, but may be related to the presence of the goethite/hematite nodular concretions whose Fe(III) could only be extracted with DCB. The relatively small change in total $\mathrm{Fe}$ and extractable $\mathrm{Fe}$ (III) in the contaminated plume sediments (Table 1) was associated with a major change in sediment color, indicating preferential biodissolution of $\mathrm{Fe}$ (III) from grain surfaces/exteriors.

\subsection{Iron Valence and Structural Environments}

\subsubsection{Room temperature Mössbauer measurements of the pristine sediment}

Mössbauer spectroscopy indicated the presence of both $\mathrm{Fe}$ (II) and $\mathrm{Fe}$ (III) valence states in the pristine sediment. The mole fraction of $\mathrm{Fe}$ (II) was highest in the coarse fraction (Fig. 5a) and decreased with decreasing particle size. The clay fraction had the highest Fe(III) content. This trend was evident from the relative intensity of high-energy component of the $\mathrm{Fe}$ (II) doublet(s) $(+2.5 \mathrm{~mm} / \mathrm{s}$; asterisk in Fig. 5). The larger proportion of $\mathrm{Fe}$ (II) in the coarse fraction was also indicated by the increased asymmetry of the central doublet $(-0.6$ to 1.3 $\mathrm{mm} / \mathrm{s}$ ). The calculated Fe(II) contribution to the spectra, (Table 2 ), was 10,20 , and $37 \%$, for the clay, silt, and coarse fractions respectively.

The Mössbauer parameters of the central doublet for the clay, silt, and coarse fractions were typical of high-spin $\mathrm{Fe}(\mathrm{III})_{\text {oct. }}$ sites associated with ferrihydrite. The intensity of the central doublet decreased with an increase in sediment particle size, suggesting a lower content of ferrihydrite. The doublet 

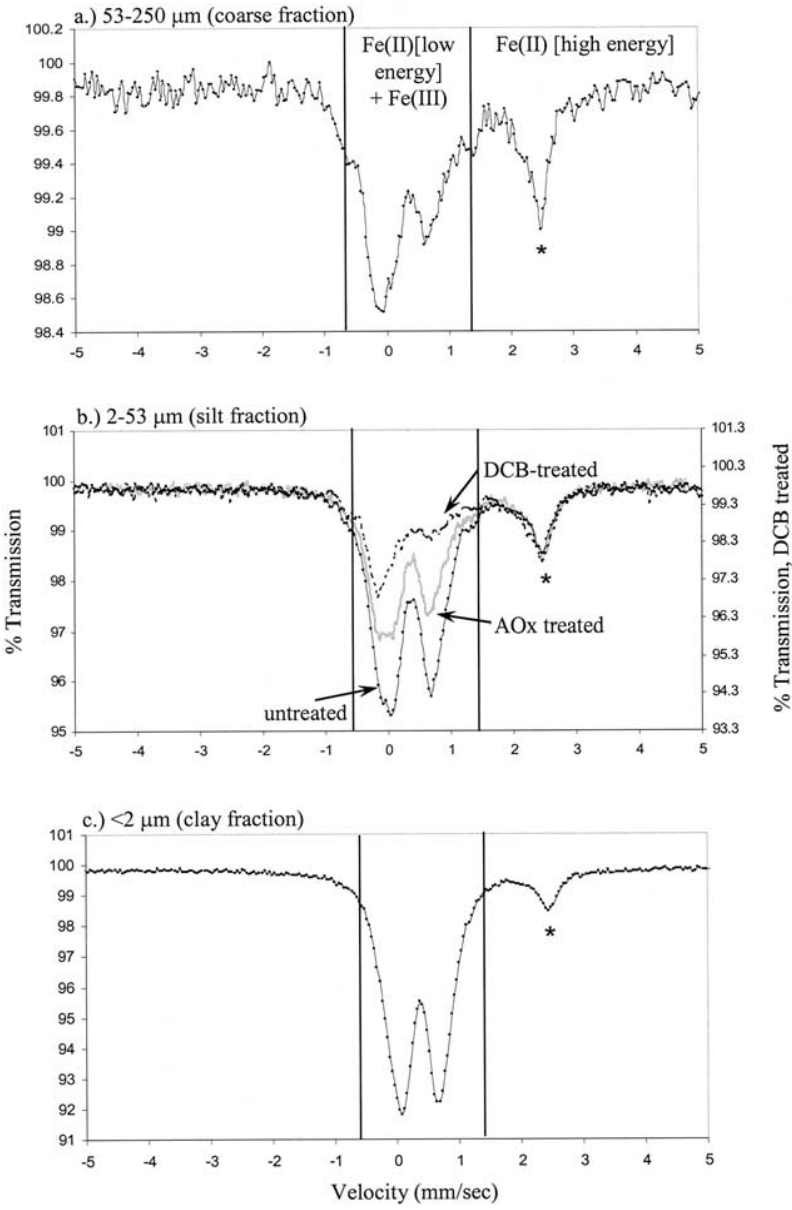

Fig. 5. Room temperature (RT) Mössbauer spectra of size fractions of the pristine sediment. Data points were connected with solid lines as a guide to the eye. (a) Fine sand $(53-250 \mu \mathrm{m})$, (b) untreated, AOx, and DCB-treated silt fraction $(2-53 \mu \mathrm{m})$, and (c) clay $(<2 \mu \mathrm{m})$. The high-energy $\mathrm{Fe}$ (II) component of clinochlore is indicated by an asterisk. Solid vertical lines indicate the position of epidote.

was not eliminated by AOx and DCB treatments of the silt fraction (Fig. 5b); dropping 30 and 60\%, respectively, in spectral area (based on $77 \mathrm{~K}$ measurements, Fig. 6, Table 2). The change in the Mössbauer spectrum with AOx and DCB treatments indicated that at least three pools of mineral $\mathrm{Fe}(\mathrm{III})$ contributed to the central doublet: "AOx-extractable $\left[\mathrm{Fe}(\mathrm{III})_{\mathrm{o}}\right]$," "DCB-extractable $\left[\mathrm{Fe}(\mathrm{III})_{\mathrm{d}}\right]$," and nonextractable $\mathrm{Fe}(\mathrm{III})$ present in silicates $\left[\mathrm{Fe}(\mathrm{III})_{\mathrm{s}}\right]$ such as clinochlore. A fourth $\mathrm{Fe}(\mathrm{III})$ phase was also evident (indicated by solid vertical lines in Fig. 5) that exhibited Mössbauer parameters characteristic of epidote, a $\mathrm{Fe}(\mathrm{III})$-silicate $\left[\mathrm{Ca}_{2}(\mathrm{Al}, \mathrm{Fe})_{3}\right.$ $\left(\mathrm{SiO}_{4}\right)_{3}(\mathrm{OH})$; Bancroft et al., 1967].

Unlike $\mathrm{Fe}(\mathrm{III})$, the $\mathrm{Fe}(\mathrm{II})$ sediment component was not affected by AOx and DCB extractions (Fig. 5b). The untreated, AOx, and DCB-treated samples exhibited identical Fe(II) peak shapes, as evident from their high-energy components at 2.6 $\mathrm{mm} / \mathrm{s}$ (Fig. 5b). The lack of change in the Fe(II) spectrum with AOx extraction (at $\mathrm{pH}=3.5$ ) indicated that carbonate $\mathrm{Fe}(\mathrm{II})$ was not present in sufficient concentration to influence the Mössbauer spectrum. Electron microscopy measurements de- scribed subsequently demonstrate that Fe-substituted carbonates do exist in low concentration in the pristine sediment.

The RT Mössbauer spectrum of the clay fraction was fitted with two $\mathrm{Fe}$ (II) doublets and two $\mathrm{Fe}$ (III) doublets (fit not shown, Table 2). The Fe(II) doublets were assigned to cis- and trans-Fe(II) sites of clinochlore. The calculated values were similar to those reported by Suttill et al. (1982) for chlorites. The central doublet in the RT Mössbauer spectrum of the clay fraction (Fig. 5c) was fitted with one doublet [mixed Fe(III)] in order quantify the mass distribution of $\mathrm{Fe}$ (III) relative to $\mathrm{Fe}$ (II) (Table 2). This approximation was necessary because it was difficult to fit unique parameters for the individual Fe(III) components to the RT data alone. Consistent with the DCB extraction (Table 1), the mixed-Fe(III) component dominated the spectral area (79\%) of the sediment. The DCB extraction, in contrast, yielded $67.7 \%$. The Mössbauer parameters of the outer Fe(III) doublet (marked with vertical lines in Figure 5c), were again, typical of epidote. This phase represented $7 \%$ of the spectral area. The RT spectra (Fig. 5) of the different size fractions of the pristine sediment indicated that mineral mass distribution, but not identity, varied with particle size.

\subsection{2. $77 \mathrm{~K}$ Mössbauer measurements of the pristine sediment}

Mössbauer spectra were collected for the pristine silt fractions (untreated, AOx, and DCB extracted) at liquid nitrogen temperature $(77 \mathrm{~K})$ to further characterize the $\mathrm{Fe}(\mathrm{III})$ oxide phases that contributed to the central doublet in Figure 5b. Unlike the RT spectrum (Fig. 5b), sextets that represented approximately $18 \%$ of the spectral area were evident in the 77 $\mathrm{K}$ spectrum of the untreated silt fraction (Fig. 6a, Table 2). The sextets also appeared upon cooling the $<2 \mu \mathrm{m}$ and 53-250 $\mu \mathrm{m}$ size fractions to $77 \mathrm{~K}$ (data not shown).

Three operationally defined Fe(III) components (doublets) were used to model the central doublet in Figure 6. These components included $\mathrm{Fe}(\mathrm{III})_{\mathrm{o}}$ (the poorly crystalline $\mathrm{Fe}(\mathrm{III})$ oxide extracted by $\mathrm{AOx}), \mathrm{Fe}(\mathrm{III})_{\mathrm{d}(\text { wo })}$ [a more crystalline $\mathrm{Fe}(\mathrm{III})$ oxide resistant to oxalate extraction, but extracted by $\mathrm{DCB}$, and $\mathrm{Fe}(\mathrm{III})_{\mathrm{s}}$ [residual $\mathrm{Fe}(\mathrm{III})$ in silicates after DCB extraction]. Accordingly, the untreated, AOx and DCB treated silt samples (Fig. 6) were fitted with three $\left[\mathrm{Fe}(\mathrm{III})_{\mathrm{o}}\right.$, $\mathrm{Fe}(\mathrm{III})_{\mathrm{d}(\text { wo })}$, and $\mathrm{Fe}(\mathrm{III})_{\mathrm{s}}$ ], two [Fe(III) $\mathrm{d}_{\mathrm{d}(\text { wo })}$ and $\left.\mathrm{Fe}(\mathrm{III})_{\mathrm{s}}\right]$, and one $\left[\mathrm{Fe}(\mathrm{III})_{\mathrm{s}}\right]$ doublets, respectively.

The model [spectral areas of $\mathrm{Fe}(\mathrm{III})_{\mathrm{o}}, \mathrm{Fe}(\mathrm{III})_{\mathrm{d}(\text { wo })}$, and $\mathrm{Fe}(\mathrm{III})_{\mathrm{s}}$ ] was incrementally assembled by first fitting the DCB extracted sediment (Fig. 6c). The AOx treated sample (Fig. 6b) was then modeled by: i) fixing the $\mathrm{Fe}(\mathrm{III})_{\mathrm{s}}$ area relative to clinochlore $\mathrm{Fe}(\mathrm{II})$, ii.) applying the Mössbauer parameters for clinochlore $\mathrm{Fe}(\mathrm{II}), \mathrm{Fe}(\mathrm{III})_{\mathrm{s}}$, and epidote $\mathrm{Fe}(\mathrm{III})$ from Figure $6 \mathrm{c}$, and iii.) adding a fourth doublet, $\mathrm{Fe}(\mathrm{III})_{\mathrm{d}(\text { wo })}$, to provide the best match of calculation with experiment. A similar approach was used to model the central doublet of the untreated sample (Fig. 6a), except in this case the peak areas of both $\mathrm{Fe}(\mathrm{III})_{\mathrm{d}(w o)}$ and $\mathrm{Fe}(\mathrm{III})_{\mathrm{s}}$ were fixed relative to clinochlore-Fe(II). This modeling approach yielded estimated concentrations of $\mathrm{Fe}(\mathrm{III})_{\mathrm{o}}$, $\mathrm{Fe}(\mathrm{III})_{\mathrm{d}(\text { wo })}$, and $\mathrm{Fe}(\mathrm{III})_{\mathrm{s}}$ of $30 \%, 12 \%$, and $12 \%$ of the total area of the untreated silt fraction, respectively (Table 2).

The Mössbauer parameters for Fe(III) o (Fig. 6a, Table 2) were typical of ferrihydrites (Zachara et al., 2002; Kukkadapu 
Table 2. Mössbauer parameters of the pristine sediment.

\begin{tabular}{|c|c|c|c|c|c|c|c|}
\hline \multirow[b]{2}{*}{ Sediment } & \multirow[b]{2}{*}{$\begin{array}{l}\text { Meas. } \\
\text { temp. }\end{array}$} & \multirow[b]{2}{*}{ Fe-species ${ }^{\mathrm{b}}$} & \multicolumn{4}{|c|}{ Mössbauer parameters ${ }^{\mathrm{a}}$} & \multirow[b]{2}{*}{$\begin{array}{l}\operatorname{Area}^{c} \\
(\%)\end{array}$} \\
\hline & & & $\begin{array}{c}\mathrm{CS}_{\mathrm{av}} \\
(\mathrm{mm} / \mathrm{s})\end{array}$ & $\begin{array}{l}\Delta_{\mathrm{av}} \text { or } \varepsilon_{\mathrm{av}} \\
(\mathrm{mm} / \mathrm{s})\end{array}$ & $\begin{array}{r}\sigma_{\Delta} \text { or } \sigma_{\mathrm{H}} \\
(\mathrm{mm} / \mathrm{s}) \text { or } \mathrm{T}\end{array}$ & $\begin{array}{l}B_{\mathrm{hf}} \\
(\mathrm{T})\end{array}$ & \\
\hline \multirow[t]{4}{*}{$<2.0 \mu \mathrm{m}$ (clay) } & \multirow[t]{4}{*}{ RT } & Clinochlore-cis-Fe(II) & 1.09 & 2.75 & 0.20 & - & 10 \\
\hline & & Clinochlore-trans-Fe(II) & 0.99 & 2.27 & 0.26 & - & 4 \\
\hline & & Epidote-Fe(III) & 0.39 & 1.90 & 0.45 & - & 7 \\
\hline & & $\begin{array}{l}\text { Mixed-Fe(III) (includes } \\
\text { clinochlore) }\end{array}$ & 0.38 & 0.64 & 0.30 & - & 79 \\
\hline \multirow[t]{7}{*}{ 2-53 $\mu \mathrm{m}$ (silt) } & \multirow[t]{7}{*}{$77 \mathrm{~K}$} & Clinochlore-Fe(II) & 1.24 & 2.77 & 0.29 & - & 20 \\
\hline & & Epidote-Fe(III) & 0.48 & 2.03 & 0.23 & - & 7 \\
\hline & & $\mathrm{Fe}(\mathrm{III})_{\mathrm{o}}$ & 0.48 & 0.72 & 0.33 & - & 30 \\
\hline & & $\mathrm{Fe}(\mathrm{III})_{\mathrm{d}(\mathrm{wo})}$ & 0.45 & 0.90 & 0.46 & - & 12 \\
\hline & & $\mathrm{Fe}(\mathrm{III})_{\mathrm{s}}$ & 0.48 & 0.71 & 0.42 & - & 12 \\
\hline & & Goethite-Fe(III) & 0.53 & -0.18 & 2 & 46.3 & 13 \\
\hline & & Hematite-Fe(III) & 0.7 & -0.15 & 0.2 & 53.5 & 5 \\
\hline \multirow{5}{*}{$\begin{array}{l}2-53 \mu \mathrm{m}^{\mathrm{d}} \text { (silt- } \\
\text { ammonium oxalate } \\
\text { treated) }\end{array}$} & \multirow[t]{5}{*}{$77 \mathrm{~K}$} & Clinochlore-Fe(II) & 1.25 & 2.84 & 0.28 & - & $39(32)$ \\
\hline & & Epidote-Fe(III) & 0.38 & 2.09 & 0.23 & - & $9(7)$ \\
\hline & & $\mathrm{Fe}(\mathrm{III})_{\mathrm{d}(\text { wo })}$ & 0.44 & 0.89 & 0.465 & - & $25(21)$ \\
\hline & & $\mathrm{Fe}(\mathrm{III})_{\mathrm{s}}$ & 0.48 & 0.71 & 0.42 & - & $26(21)$ \\
\hline & & Magnetic-Fe(III) $)^{\mathrm{e}}$ & - & - & - & - & (18) \\
\hline \multirow{3}{*}{$\begin{array}{l}2-53 \mu \mathrm{m} \text { (silt-DCB } \\
\text { treated) }\end{array}$} & \multirow[t]{3}{*}{$77 \mathrm{~K}$} & Clinochlore-Fe(II) & 1.24 & 2.77 & 0.29 & - & 55 \\
\hline & & Epidote-Fe(III) & 0.48 & 2.03 & 0.23 & - & 7.5 \\
\hline & & $\mathrm{Fe}(\mathrm{III})_{\mathrm{s}}$ & 0.48 & 0.70 & 0.42 & - & 37 \\
\hline \multirow{5}{*}{ 53-250 $\mu \mathrm{m}$ (coarse) } & \multirow[t]{5}{*}{$77 \mathrm{~K}$} & Clinochlore-Fe(II) & 1.25 & 2.78 & 0.28 & - & 37 \\
\hline & & Epidote-Fe(III) & 0.45 & 2.03 & 0.27 & - & 13 \\
\hline & & $\mathrm{Fe}(\mathrm{III})_{\mathrm{s}}$ & 0.48 & 0.72 & 0.41 & - & 31 \\
\hline & & Goethite-Fe(III) & 0.57 & -0.17 & 1.94 & 49.7 & 14 \\
\hline & & Hematite-Fe(III) & 0.67 & -0.03 & 0.8 & 52.9 & 6 \\
\hline \multirow[t]{6}{*}{$<2.0 \mathrm{~mm}$} & \multirow[t]{6}{*}{$77 \mathrm{~K}$} & Clinochlore-Fe(II) & 1.25 & 2.84 & 0.22 & - & 48 \\
\hline & & Epidote-Fe(III) & 0.47 & 2.17 & 0.23 & - & 9 \\
\hline & & $\mathrm{Fe}(\mathrm{III})_{\mathrm{d}(\text { wo })}$ & 0.45 & 0.90 & 0.46 & - & 6 \\
\hline & & $\mathrm{Fe}(\mathrm{III})_{\mathrm{s}}$ & 0.48 & 0.71 & 0.42 & - & 18 \\
\hline & & Goethite-Fe(III) & 0.54 & -0.18 & 2.54 & 47.0 & 14 \\
\hline & & Hematite-Fe(III) & 0.81 & -0.23 & 0.2 & 53.9 & 5 \\
\hline \multirow{6}{*}{$\begin{array}{l}<2.0 \mathrm{~mm} \text { (ammonium } \\
\text { oxalate treated) }\end{array}$} & \multirow[t]{6}{*}{$77 \mathrm{~K}$} & Clinochlore-Fe(II) & 1.25 & 2.83 & 0.25 & - & 43 \\
\hline & & Epidote-Fe(III) & 0.49 & 2.17 & 0.23 & - & 11 \\
\hline & & $\mathrm{Fe}(\mathrm{III})_{\mathrm{d}(\text { wo })}$ & 0.45 & 0.90 & 0.46 & - & 8 \\
\hline & & $\mathrm{Fe}(\mathrm{III})_{\mathrm{s}}$ & 0.48 & 0.71 & 0.42 & - & 17 \\
\hline & & Goethite-Fe(III) & 0.57 & -0.21 & 2.93 & 47.6 & 17 \\
\hline & & Hematite-Fe(III) & 0.84 & -0.12 & 0.2 & 54.0 & 4 \\
\hline \multirow[t]{3}{*}{$<2.0 \mathrm{~mm}(\mathrm{DCB}$ treated $)$} & \multirow[t]{3}{*}{$77 \mathrm{~K}$} & Clinochlore-Fe(II) & 1.24 & 2.85 & 0.24 & - & 62 \\
\hline & & Epidote-Fe(III) & 0.48 & 2.08 & 0.23 & - & 14 \\
\hline & & $\mathrm{Fe}(\mathrm{III})_{\mathrm{s}}$ & 0.50 & 0.68 & 0.37 & - & 24 \\
\hline
\end{tabular}

${ }^{a}$ Values derived from Voigt-based fits (Rancourt and Ping, 1991). $\mathrm{CS}_{\mathrm{av}}$ is center shift, $\Delta_{\mathrm{av}}$ or $\varepsilon_{\mathrm{av}}$ is quadrupole splitting or quadrupole shift, $\sigma_{\Delta}$ or $\sigma_{\mathrm{H}}$ is hyperfine distribution width, and $B_{\mathrm{hf}}$ is magnetic hyperfine field.

${ }^{\mathrm{b}} \mathrm{DCB}$ extractable $\mathrm{Fe}(\mathrm{III})=\left[\mathrm{Fe}_{\mathrm{o}}+\mathrm{Fe}_{\mathrm{d}(\text { wo })}+\right.$ magnetic $\left.\mathrm{Fe}(\mathrm{III})\right]$.

c The spectral area is a semi-quantitative measure of mass.

${ }^{\mathrm{d}}$ The magnetic Fe(III) fraction is not included in the fit because the spectrum only ranged between -5 to $+5 \mathrm{~mm} / \mathrm{sec}$. The areas reported in parentheses were calculated assuming magnetic Fe(III) contribution identical to that derived for the untreated sample.

e Goethite + hematite.

${ }^{\mathrm{f}}$ Nature of $\mathrm{Fe}(\mathrm{III})$ is not certain.

et al., 2003). It was not possible to unambiguously assign the $\mathrm{Fe}(\mathrm{III})_{\mathrm{d}(\text { wo })}$ doublet to a specific $\mathrm{Fe}(\mathrm{III})$ oxide because small particle size and/or isomorphous substitution of foreign ions in crystalline $\mathrm{Fe}(\mathrm{III})$-oxides results in a doublet rather than a sextet due to super paramagnetic relaxation. The Mössbauer parameters derived for residual $\mathrm{Fe}(\mathrm{III})_{\mathrm{s}}$ from Figure 6c (Table 2) were also not easily matched with other known phases.

The hyperfine feature associated with crystalline $\mathrm{Fe}$ (III) oxides (e.g., peaks at approximately $-7.5,-3.5,5$, and $8 \mathrm{~mm} / \mathrm{s}$, Fig. 6a) was fitted with two sextets (Table 2). The derived magnetic hyperfine field $B_{\mathrm{hf}}$ value of $46.3 \mathrm{~T}$ for the major sextet (13\% spectral area) was similar to the values reported for small particle, or poorly crystalline goethite $(<15 \mathrm{~nm}$, Janot et al., 1973), Al substituted goethite ( $>12 \%$, Vandenberghe et al., 1990 ), and maghemite (Murad, 1988). The derived $B_{\mathrm{hf}}$ value of $53.3 \mathrm{~T}$ for the minor sextet (5\% spectral area) was typical of hematite (Fysh and Clark, 1982). The absence of sextets in the DCB-treated sample (Fig. 6c) was consistent with the presence of goethite and hematite in the untreated sample, as these crystalline Fe(III) oxides are removed by DCB extraction. The concentrations of AOx and DCB extractable Fe(III) oxides estimated from Mössbauer spectroscopy of the silt fraction (Table 2) showed reasonable agreement with the extraction values (Table 1). Our measurements implied that $\mathrm{Fe}(\mathrm{III})_{\mathrm{o}}$ ex- 
a.) Untreated

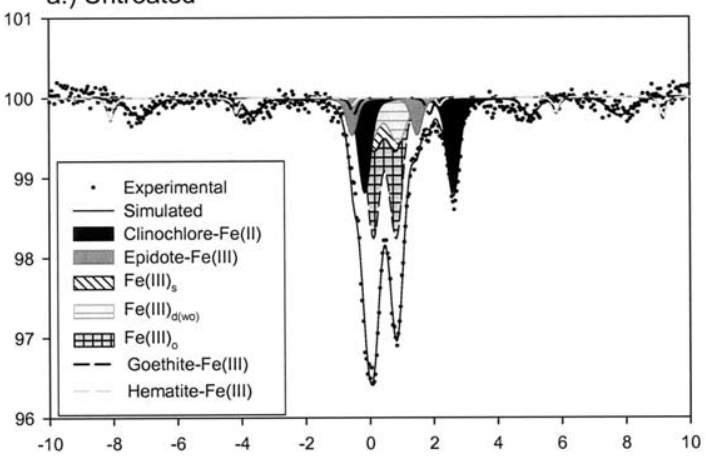

b.) Ammonium oxalate treated

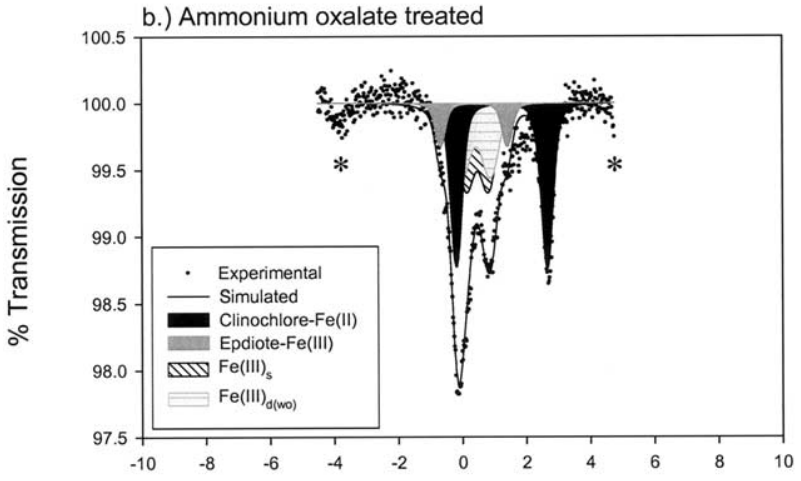

c.) DCB treated

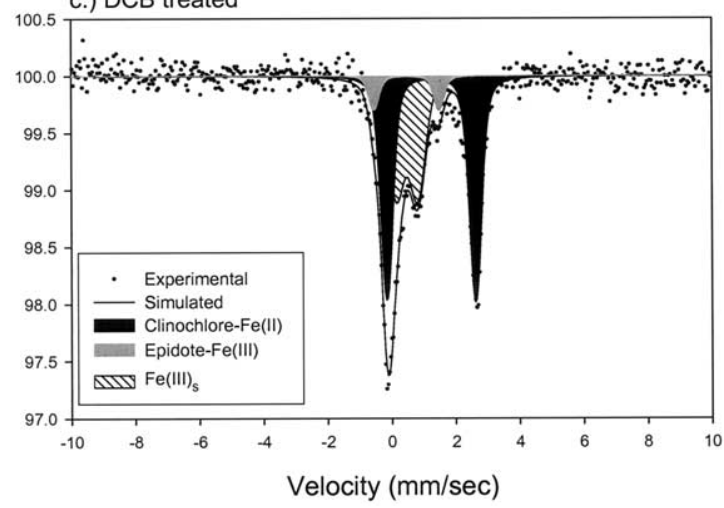

Fig. 6. $77 \mathrm{~K}$ Mössbauer spectra and model simulations of the pristine silt-sized fraction $(2-53 \mu \mathrm{m})$. (a) Spectrum for the untreated fraction obtained from -10 to $+10 \mathrm{~mm} / \mathrm{s}$. (b) AOx-treated spectrum obtained from -5 to $+5 \mathrm{~mm} / \mathrm{s}$. Sextet peaks 2 and 5 are indicated by an asterisk. (c) DCB-treated spectrum obtained from -10 to $+10 \mathrm{~mm} / \mathrm{s}$.

isted as coatings or intergrain precipitates on lithic fragments predominantly in the clay and silt fractions.

Mössbauer spectra $(77 \mathrm{~K}$ ) were collected from the $<2.0 \mathrm{~mm}$ pristine sediment, as well as AOx- and DCB-treated subsamples (Fig. 7) to facilitate comparisons between the bulk pristine and contaminated sediments. A modeling approach like that employed for Figure 6 was again used (see results of modeling in Table 2). Consistent with the observations of Figure 5, where Fe(II) content was observed to increase with sediment particle size, the spectrum of the untreated pristine sample was dominated by clinochlore-Fe(II) (Fig. 7a). Sextets associated with hematite and goethite were also evident, as well as doublets resulting from epidote and $\mathrm{Fe}(\mathrm{III})_{\mathrm{s}}$. AOx-treatment of the $<2.0 \mathrm{~mm}$ pristine sediment had little effect on its Mössbauer spectrum (Fig. 7b), attesting to the low overall concentration of poorly crystalline $\mathrm{Fe}(\mathrm{III})$ oxide [e.g., $\mathrm{Fe}(\mathrm{III})_{\mathrm{o}}$ ]. DCB extraction eliminated the sextet feature associated with goethite and hematite (Fig. 7), and removed spectral mass from the central doublet attributed to $\mathrm{Fe}(\mathrm{III})_{\mathrm{d}(\text { wo })}$ (Table 2). The invisibility of $\mathrm{Fe}(\mathrm{III})_{\mathrm{o}}$ in the bulk sediment was consistent with the low values of AOx-extractable Fe(III) in the $<2.0 \mathrm{~mm}$ sediment (Table 1).
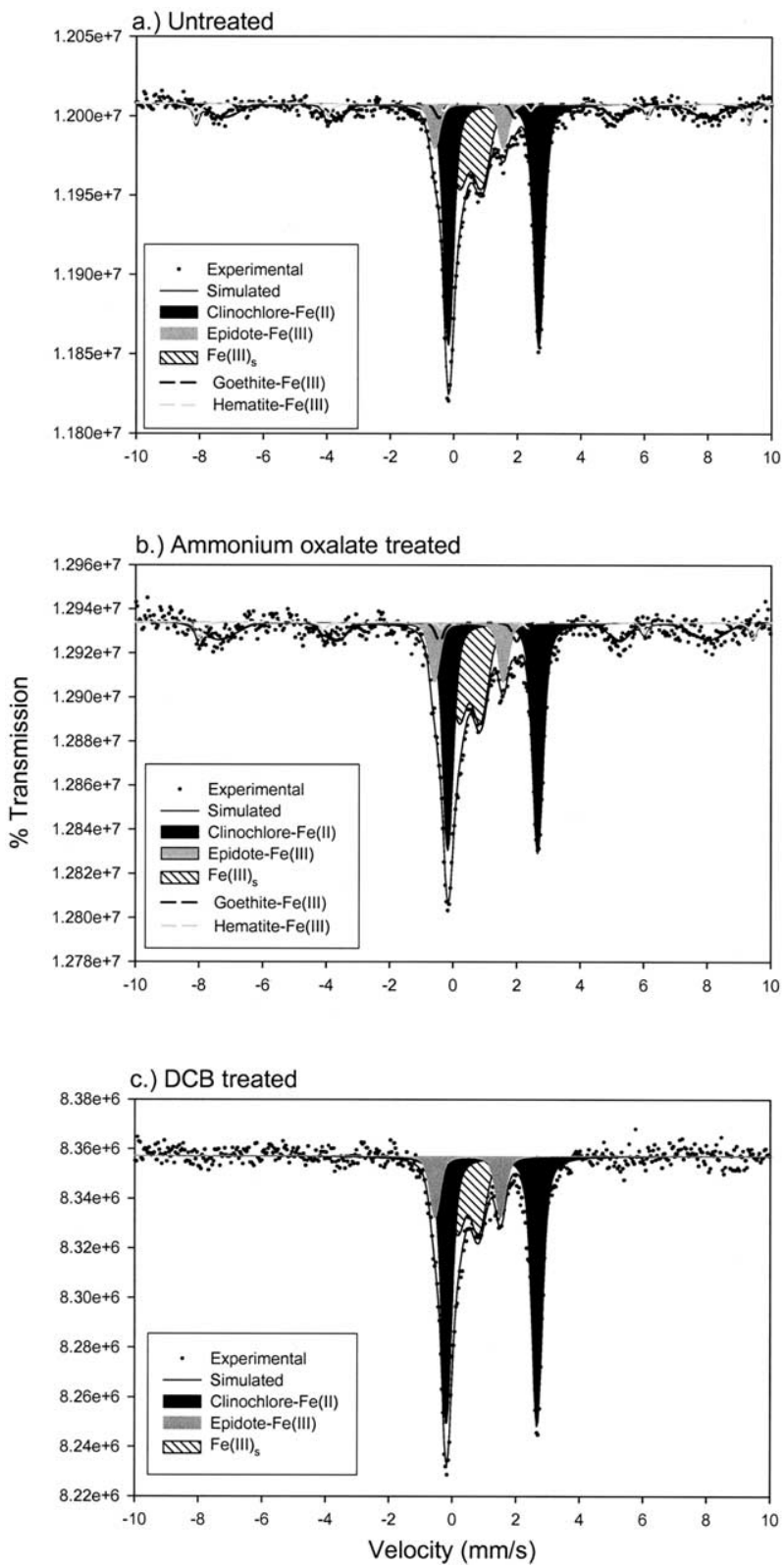

Fig. 7. $77 \mathrm{~K}$ Mössbauer spectra and model simulations of the $<2.0$ $\mathrm{mm}$ pristine sediment. (a) Untreated sediment. (b) AOx-treated sediment. (c) DCB-treated sediment. 


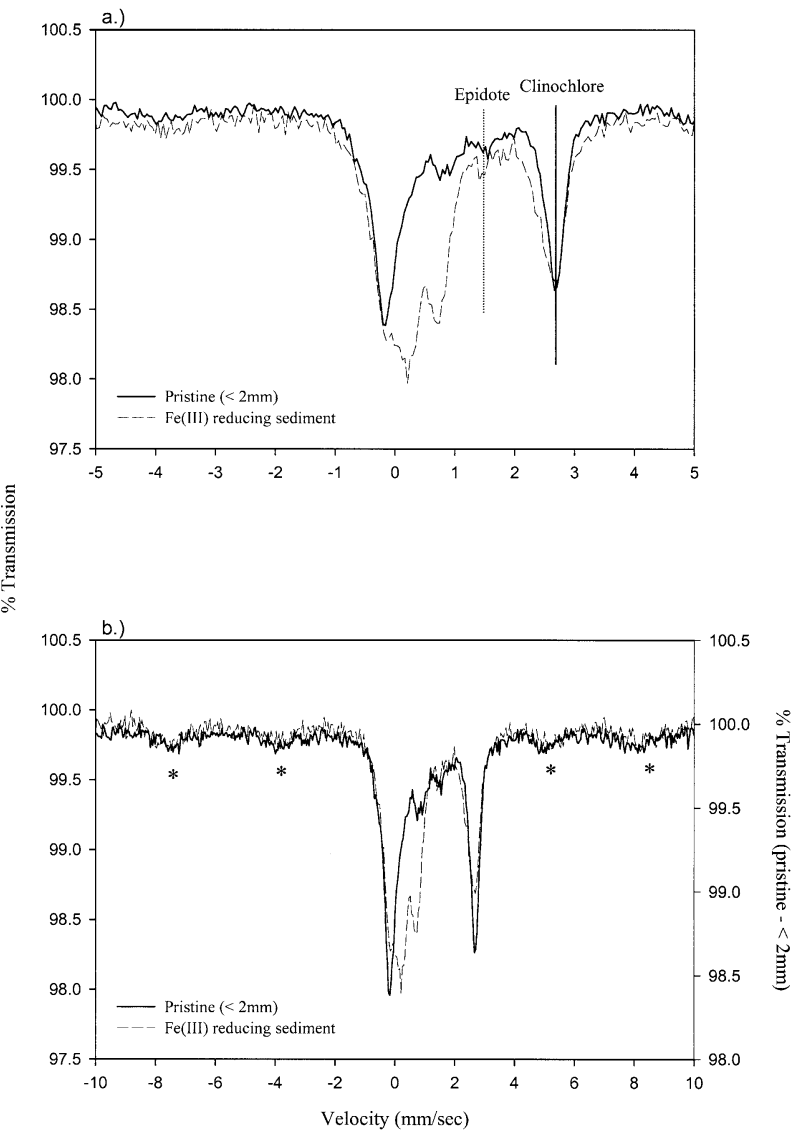

Fig. 8. $77 \mathrm{~K}$ Mössbauer spectra of the $<2.0 \mathrm{~mm}$ pristine sediment and the $\mathrm{Fe}$ (III)-reducing sediment. (a) Spectra at -5 to $+5 \mathrm{~mm} / \mathrm{s}$ showing a detailed comparison of chlorite and epidote peaks. (b) Spectra at -10 to $+10 \mathrm{~mm} / \mathrm{s}$. An asterisk indicates sextet peaks due to magnetic $\mathrm{Fe}(\mathrm{III})$.

\subsection{3. $77 \mathrm{~K}$ Mössbauer measurements of the contaminated sediments}

The $77 \mathrm{~K}$ Mössbauer spectra of the source and Fe(III)reducing zones were significantly different from the pristine sediment (Figs. 8 and 10). However, the clinochlore and epidote peaks in the contaminated sediments were identical to the pristine sediment, indicating their stability under reducing conditions.

The magnetic Fe(III) feature (sextets; asterisks in Fig. 8b) attributed to goethite and hematite in the pristine sediment (Fig. $6 \mathrm{a}$ and Figs. 7a,b) was also observed in the Fe(III) reducing sediment. These sextets, however, were not apparent in the 77 K spectrum of source sediment (Fig. 9) where a doublet feature dominated its spectrum. Apparently these phases were removed as a consequence of subsurface DIRB activity, or they did not exist in the pristine sediments in this region of the plume.

The relative contents of the various Fe-mineral phases in the two contaminated sediments were obtained by fitting their $77 \mathrm{~K}$ spectra (Fig. 10). To model the data, the Mössbauer parameters of clinochlore and epidote, and magnetic-Fe(III) due to goethite and hematite [in the $\mathrm{Fe}$ (III) reducing sediment] were fixed at values used for the pristine sediment (Table 2). Also, the Mössbauer parameters of $\mathrm{Fe}(\mathrm{III})_{\mathrm{s}}$ and its content [relative to
clinochlore-Fe(II)] were fixed at values fitted in the DCB treated pristine sediment (e.g., Fig. 7c). Both of these approximations helped quantify the nonsilicate $\mathrm{Fe}$ contribution $\left[\mathrm{Fe}(\mathrm{III})_{\mathrm{ns}}\right]$ to the central doublet (Fig. 10, Table 3). Unlike our modeling of the pristine sediment fractions, we did not divide the $\mathrm{Fe}(\mathrm{III})_{\mathrm{ns}}$ into separate $\mathrm{Fe}(\mathrm{III})_{\mathrm{o}}$ and $\mathrm{Fe}(\mathrm{III})_{\mathrm{d}(\text { wo })}$ fractions. Textural differences between the pristine sediment (more coarse) and the contaminated sediments (more fine) precluded such approach. Unexpected was a significant contribution of nonsilicate $\mathrm{Fe}$ (III) [e.g., authigenic Fe(III) oxide] to the central doublets of both anoxic plume sediments $(7 \%$ in source and $26 \%$ in Fe(III)-reducing sediment; Table 3) when this component [e.g., $\mathrm{Fe}(\mathrm{III})_{\mathrm{d}(\text { wo })}$ ] was barely evident in spectra for the $<$ $2.0 \mathrm{~mm}$ pristine sediment (Fig. 7, Table 2). We believe that our samples from the source and $\mathrm{Fe}(\mathrm{III})$ reducing zones originated from a finer textured facies of the aquifer than did the pristine sediments.

The $\mathrm{Fe}(\mathrm{III})_{\mathrm{ns}}$ content of the source sediment derived from the spectral analysis $(7 \%)$ was similar to that extracted by DCB (Table $1 ; 10 \%$ of $\mathrm{Fe}_{\text {тот }}$ ). A $77 \mathrm{~K}$ Mössbauer spectrum was measured on the DCB-extracted source sediment (Fig. 9) to document that the fitted $\mathrm{Fe}(\mathrm{III})_{\mathrm{ns}}$ fraction was a reducible $\mathrm{Fe}$ (III) oxide, and not an artifact of our assumption of a constant $\left[\mathrm{Fe}(\mathrm{III})_{\mathrm{s}}\right] /$ chlorite-[Fe(II)] ratio. DCB-extraction removed spectral area from the central doublet, indicating that authigenic $\mathrm{Fe}(\mathrm{III})$ oxides [e.g., Fe(III) $)_{\text {ns }}$ ] existed in the source sediment. The high and low field regions of the two spectra (untreated and DCB-treated) were virtually identical, indicating that the crystalline $\mathrm{Fe}$ (III) oxides (goethite and hematite) that contributed to the sextets in the pristine and Fe(III) reducing sediments were depleted in the source sediment.

The reducible Fe(III)-oxide fraction of the Fe(III)-reducing zone sediment estimated from the spectral analysis of Figure 10a [sum of $\mathrm{Fe}(\mathrm{III})_{\mathrm{ns}}$ and goethite and hematite; Table 3], was significantly higher than for the source sediment. The difference between the $\mathrm{Fe}(\mathrm{III})$ reducing and source sediments was apparent in the width of the central doublet. This result indicated that $\mathrm{Fe}$ (III) oxide depletion near the source of contamination was higher than in the Fe(III) reducing region of the plume.

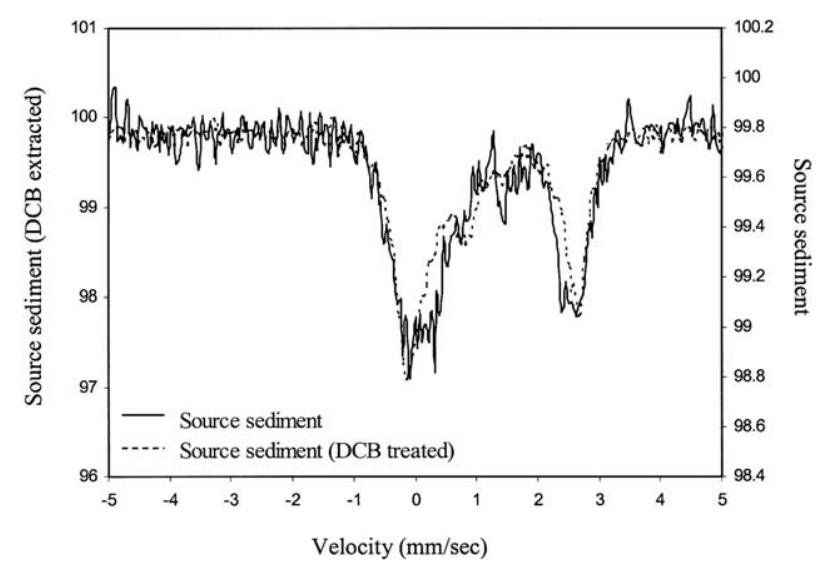

Fig. 9. $77 \mathrm{~K}$ Mössbauer spectra of the source sediment and the source sediment after DCB extraction $(-5$ to $+5 \mathrm{~mm} / \mathrm{s})$. 


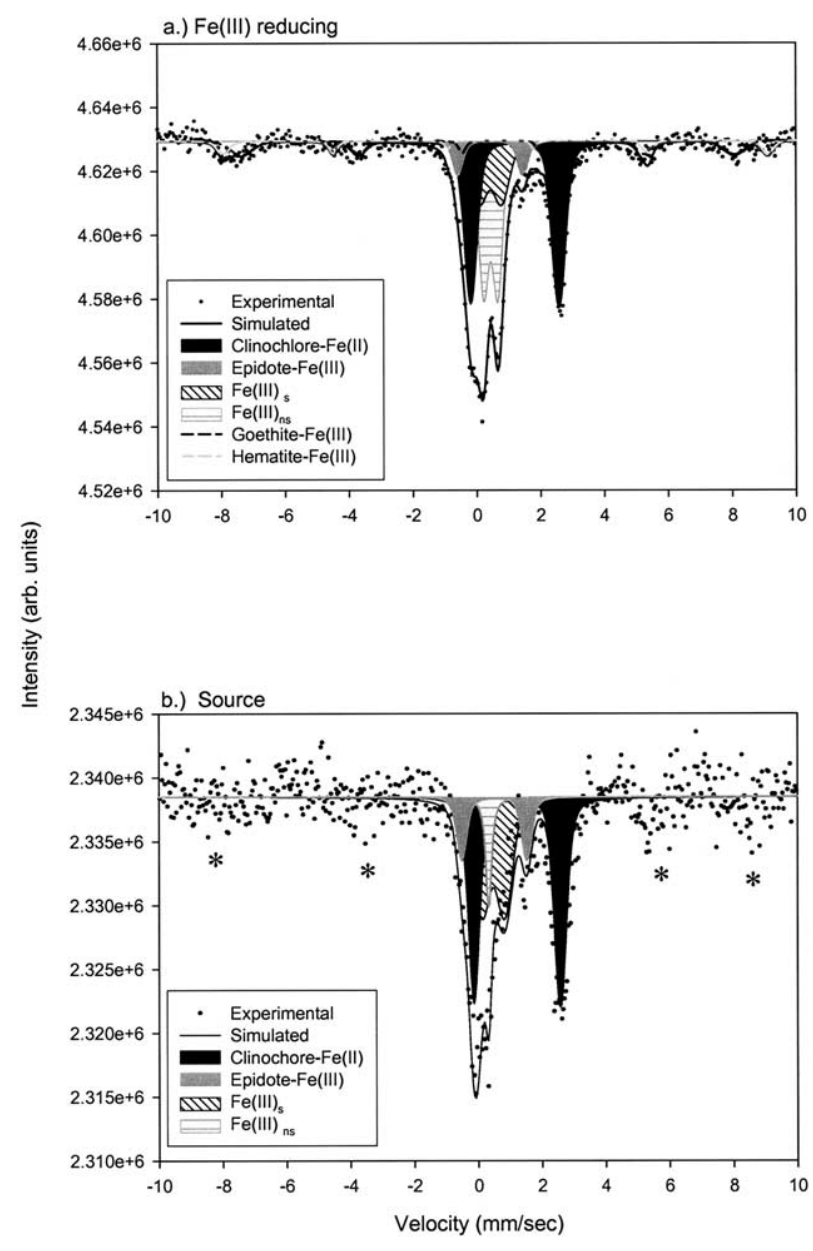

Fig. 10. $77 \mathrm{~K}$ Mössbauer spectra and model simulations of (a) the $\mathrm{Fe}(\mathrm{III})$ reducing sediment and (b) the source zone sediment.

\subsection{Electron Microscopy and EDS Analyses of Mineral Separates}

\subsubsection{Nodular concretions}

Nodular concretions isolated from the pristine sediments were analyzed to establish whether these mineral particles could conceivably be dissolved under Fe(III)-reducing conditions. The nodular concretions were primarily composed of goethite and hematite, but also contained significant inclusions of quartz (Fig. 4; Figs. 11a,b). The concretions were dense with minimal internal porosity. Consistent with the XRD pattern, iron was the primary metal cation in the concretions, followed by lesser amounts $\mathrm{Si}, \mathrm{Al}$, and Mn (Table 4). The concretions exhibited a visible rind $(20 \mu \mathrm{m})$ in cross section (not shown), that was also evident in the EDS image (Fig. 11a). Quantitative spot analyses indicated that the rind was partially deplete in $\mathrm{Mn}$ and $\mathrm{Fe}$ (Table 4), possibly indicating the temporal occurrence of $\mathrm{Fe}(\mathrm{III}) / \mathrm{Mn}(\mathrm{III} / \mathrm{IV})$ reducing conditions in the pristine aquifer.

\subsubsection{Carbonates from the pristine and contaminated zones}

Carbonates isolated from the pristine and contaminated zones were analyzed to determine if $\mathrm{Fe}$ (II)-carbonate precipitation in the anoxic zone could be verified. Many carbonate lithic fragments from the pristine sediments contained $\mathrm{Fe}$ as a minor substituent that was distributed both homogeneously and heterogeneously (Fig. 12). Fe valence was not measured on these particles but $\mathrm{Fe}$ that was internal to the carbonate particles was presumed to be $\mathrm{Fe}(\mathrm{II})$. The heterogeneous particles also showed discontinuous surface precipitation of $\mathrm{Fe}$ and a faint, meshlike internal network of Fe within the carbonate matrix (Fig. 12d). The internal zones of Fe concentration were compositionally distinct precipitates of ferroan calcite that outlined grain boundaries and recrystallized zones (Fig. 13). The ubiquitous presence of these ferroan calcite cements, and their crystallization within the rock fabric implied a detrital origin. A different pattern of $\mathrm{Fe}$ accumulation was observed in other pristine sediment carbonate particles (Fig. 14a) where Fe was localized at specific regions of the surface, and in intragrain channels linked to the aqueous phase. We surmised but did not document that these Fe-zones were Fe(III) oxides.

Carbonate particles isolated from source zone sediments where bacterial $\mathrm{Fe}(\mathrm{III})$ reduction was greatest exhibited similar characteristics to those from pristine sediment. Carbonate particles with both homogeneous and heterogeneous Fe distribution were isolated and analyzed. The intergranular ferroan calcite cement in source zone carbonates was distinctive in

Table 3. $77 \mathrm{~K}$ Mössbauer parameters of the contaminated sediments.

\begin{tabular}{|c|c|c|c|c|c|c|}
\hline \multirow[b]{2}{*}{ Sediment } & \multirow[b]{2}{*}{ Fe-species } & \multicolumn{4}{|c|}{ Mössbauer parameters ${ }^{\mathrm{a}}$} & \multirow[b]{2}{*}{ Area $^{\mathrm{b}}(\%)$} \\
\hline & & $\begin{array}{c}\mathrm{CS}_{\mathrm{av}} \\
(\mathrm{mm} / \mathrm{s})\end{array}$ & $\begin{array}{c}\Delta_{\mathrm{av}} \text { or } \varepsilon_{\mathrm{av}} \\
(\mathrm{mm} / \mathrm{s})\end{array}$ & $\begin{array}{c}\sigma \Delta \text { or } \sigma \\
(\mathrm{mm} / \mathrm{s}) \text { or } \mathrm{T}\end{array}$ & $B_{\mathrm{hf}}(\mathrm{T})$ & \\
\hline \multirow[t]{6}{*}{$\mathrm{Fe}(\mathrm{III})$ reducing sediment } & Clinochlore-Fe(II) & 1.24 & 2.76 & 0.32 & - & 36 \\
\hline & Epidote-Fe(III) & 0.48 & 2.03 & 0.23 & - & 6 \\
\hline & $\mathrm{Fe}(\mathrm{III})_{\mathrm{s}}$ & 0.48 & 0.71 & 0.42 & - & 16 \\
\hline & $\mathrm{Fe}(\mathrm{III})_{\mathrm{ns}}$ & 0.48 & 0.44 & 0.22 & - & 26 \\
\hline & Goethite-Fe(III) & 0.61 & -0.21 & 1.9 & 47.9 & 10 \\
\hline & Hematite-Fe(III) & 0.57 & 0.07 & 0.8 & 52.9 & 6 \\
\hline \multirow[t]{4}{*}{ Source } & Clinochlore-Fe(II) & 1.22 & 2.71 & 0.29 & - & 47 \\
\hline & Epidote-Fe(III) & 0.51 & 2.03 & 0.23 & - & 13 \\
\hline & $\mathrm{Fe}(\mathrm{III})_{\mathrm{s}}$ & 0.47 & 0.72 & 0.42 & - & 33 \\
\hline & $\mathrm{Fe}(\mathrm{III})_{\mathrm{ns}}$ & 0.33 & 0.06 & 0.1 & - & 7 \\
\hline
\end{tabular}

\footnotetext{
${ }^{\text {a } V a l u e s ~ d e r i v e d ~ f r o m ~ V o i g t-b a s e d ~ f i t s ~(R a n c o u r t ~ a n d ~ P i n g, ~ 1991) . ~}$
}

$\mathrm{b}$ The spectral area is a semi-quantitative measure of mass. 
a.)

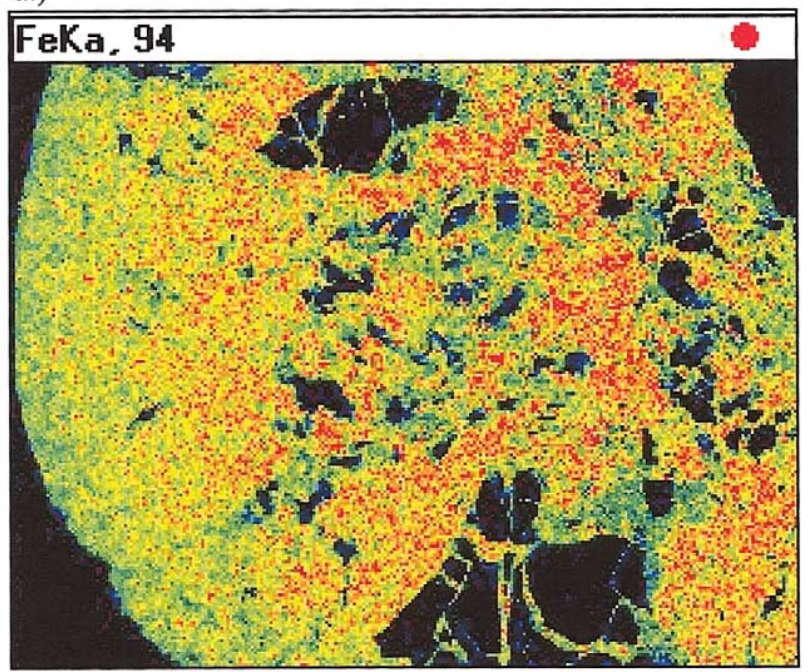

b.)

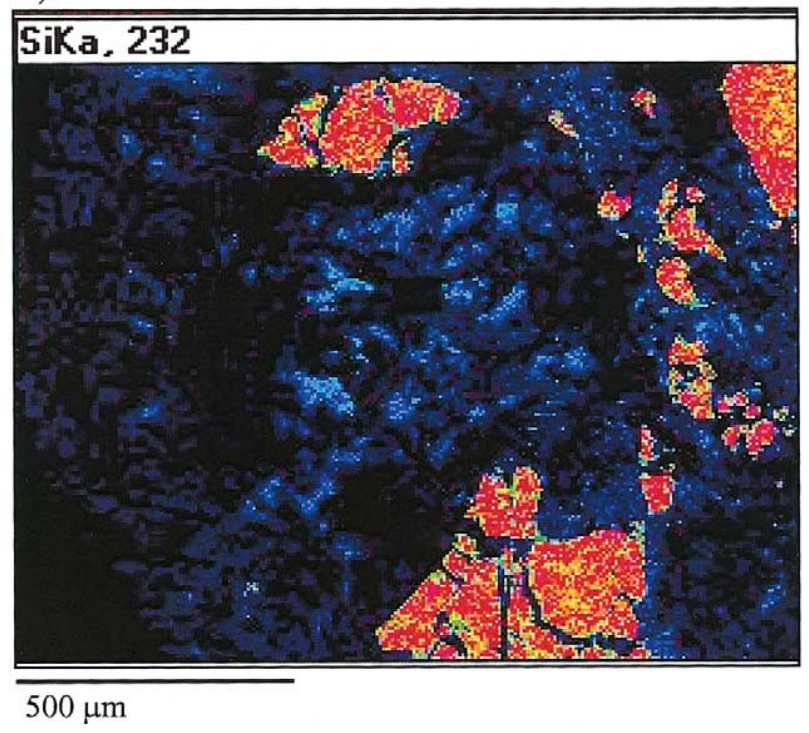

Fig. 11. EDS cross-sectional chemical images of a hematite/goethitecontaining nodular concretion from the pristine sediment, (a) Fe and (b) Si. Color scales indicate relative concentration. Red is the highest concentration, decreasing to yellow, then green and blue. Specific analyses for the Fe domains in (a) are reported in Table 4. The XRD of this nodule is reported in Figure 4.

cross section (Fig. 14b) and small crystallites with nascent rhombohedral morphology were evident in plan view (Fig. 14c) as components of larger, carbonate cemented aggregates. A potentially distinguishing characteristic of carbonates from the source zone was the presence of generally continuous particle coatings of Fe (compare Fig. 14b with Fig. 14a), that could represent ferroan calcite or siderite precipitated as an indirect product of bacterial $\mathrm{Fe}(\mathrm{III})$ reduction.

In spite of these many examples of $\mathrm{Fe}$ in carbonate association, spectral contributions of carbonate-Fe(II) were not observed in the Mössbauer spectra of any of the size fractions of the pristine or the source zone sediment. The low concentration of $\mathrm{Fe}$ in this structural environment prevented its identification.
Table 4. Chemical analyses of nodular concretions by EDS.

\begin{tabular}{ccccc}
\hline \multicolumn{5}{c}{ Core } \\
$\mathrm{n}^{\mathrm{a}}$ & $\mathrm{Al}$ & $\mathrm{Si}$ & $\mathrm{Mn}$ & $\mathrm{Fe}$ \\
\hline 9 & $0.822( \pm .706)$ & $5.60( \pm 2.02)$ & $1.37( \pm 0.19)$ & $69.0( \pm 8.36)$ \\
\hline \multicolumn{5}{c}{ Rind } \\
$\mathrm{n}$ & $\mathrm{Al}$ & $\mathrm{Si}$ & $\mathrm{Mn}$ & $\mathrm{Fe}$ \\
\hline 10 & $1.06( \pm 0.910)$ & $9.94( \pm 2.63)$ & $0.412( \pm 0.125)$ & $56.5( \pm 6.59)$ \\
\hline
\end{tabular}

${ }^{\mathrm{a}} \mathrm{n}=$ number of spot measurements.

The high field component of the paramagnetic doublet for $\mathrm{Fe}$ (II) in carbonate falls at approximately $2.2 \mathrm{~mm} / \mathrm{s}$ (Ono and Ito, 1964; Kukkadapu et al., 2001), as compared to $2.4 \mathrm{~mm} / \mathrm{s}$ for chlorite.

\section{DISCUSSION}

\subsection{Fe Mineralogy of the Pristine Sediment}

The pristine sediment contained both $\mathrm{Fe}$ (II) and $\mathrm{Fe}$ (III) minerals. Ferrous iron represented approximately $48 \%$ (based on Mössbauer fit; Table 1) of the total iron in the $<2.0 \mathrm{~mm}$ pristine sediment. Clinochlore was the primary Fe(II) repository, with the remainder occurring as detrital magnetite and ferroan-calcite intergrain fillings within silt-sized carbonate lithic fragments.

The ferric iron mineralogy was complex (Table 5). Mössbauer spectroscopy indicated that approximately $20 \%$ of the $\mathrm{Fe}(\mathrm{III})$ existed in structural association in epidote and other silicates (e.g., clinochlore, muscovite, and others). The remainder of the $\mathrm{Fe}$ (III) existed as $\mathrm{Fe}(\mathrm{III})$ oxides of differing forms. Detrital magnetite $\left[\mathrm{Fe}(\mathrm{II}) \mathrm{Fe}(\mathrm{III})_{2} \mathrm{O}_{4}\right]$, identified by its dodeca-

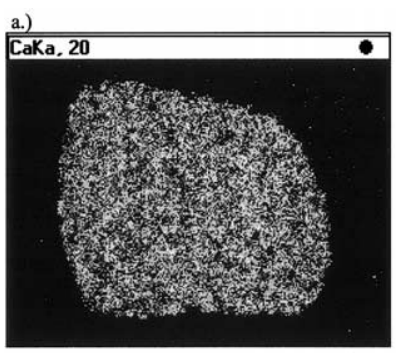

b.)
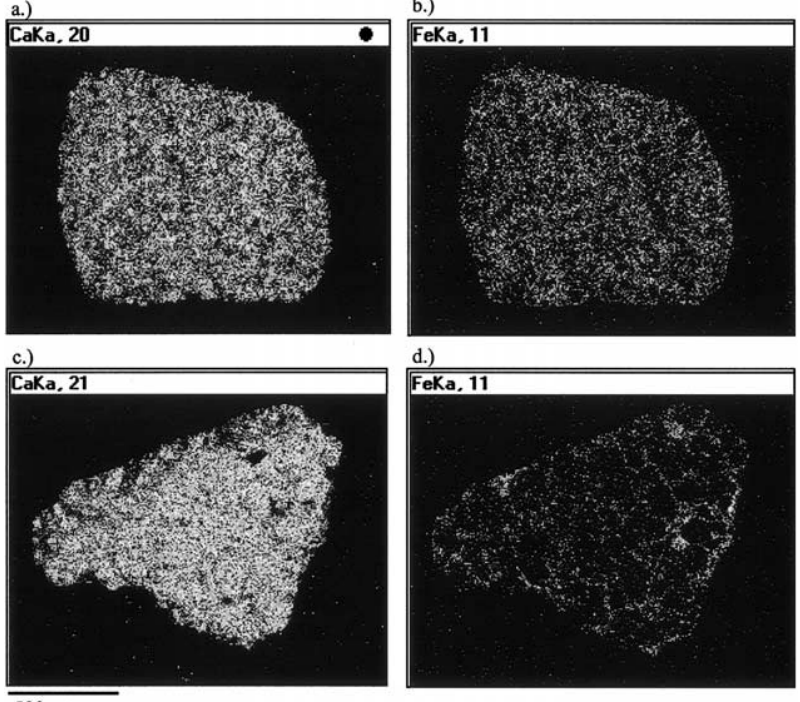

Fig. 12. EDS cross-sectional chemical images of two Fe-containing carbonate grains from the pristine sediment, (a) $\mathrm{Ca}$ and (b) $\mathrm{Fe}$ for the homogeneous carbonate, and (c) $\mathrm{Ca}$ and (d) Fe for the heterogeneous carbonate. White intensity denotes relative concentration. 


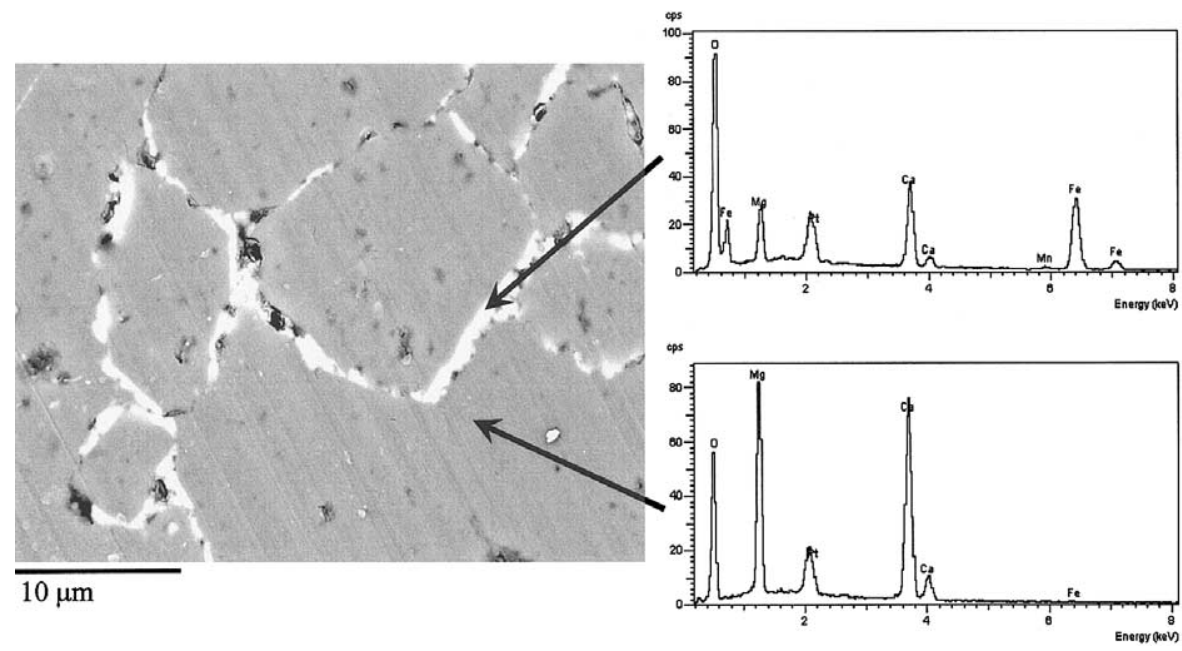

Fig. 13. Backscattered electron SEM image and EDS analyses of high-Fe internal regions of the heterogeneous carbonate. Light (white) regions are electron dense regions associated with elements of higher atomic weight (e.g., Fe). The gray regions are the dolomite matrix.

hedral morphology and XRD pattern, was common at the $0.5 \%$ mass level in the pristine and contaminated sediments. Mössbuaer spectroscopy of the magnetite phase showed it to be relatively unweathered (spectra not shown). One curious detrital form of $\mathrm{Fe}(\mathrm{III})$ oxide were the silt- and sand-sized nodular concretions (Figs. 1, 4, and 11) that contained hematite as a dominant phase. The morphology and habit of the concretions suggested origin in the taconitic, iron bearing sediments south and west of Lake Superior that are mined for hematite. A third form of $\mathrm{Fe}(\mathrm{III})$ oxide was observed primarily by optical microscopy. These were small, goethite and hematite precipitates on quartz and feldspar grain surfaces. The concretions and surface precipitates, combined, yielded the $77 \mathrm{~K}$ sextet features attributed to goethite and hematite in the bulk pristine sediment (Fig. 7). In contrast, only surface precipitates contributed to the $77 \mathrm{~K}$ sextets in the pristine silt fraction (Fig. 6) and the Fe(III) reducing sediment (Fig. 10), because concretions were not present in these materials. It is suspected that the goethite and hematite associated with both the concretions and the surface precipitates were of similar composition or crystallite size, because neither showed magnetic ordering in their room temperature Mössbauer spectra (see Fig. 5).

A fourth form of $\mathrm{Fe}(\mathrm{III})$ oxide, and the one most important to DIRB as an electron acceptor, was associated with the central Mössbauer doublet of the pristine silt and clay fractions (Figs. 5 and 6) and the Fe(III) reducing and source sediments (Fig. 10). This material increased in mass percent in the smaller size fractions of the pristine sediment (Fig. 5), and was likely authigenic, finely distributed Fe(III) oxide. Approximately $60 \%$ of this material was soluble in AOx and the remainder in DCB. The room temperature Mössbauer parameters of the doublet were similar to those reported for 2-line (Zachara et al., 2002) and 6-line ferrihydrite (Kukkadapu et al., 2003). The incomplete solubility of this phase in AOx implied partial crystallinity, possibly as 6-line ferrihydrite or cryptocrystalline goethite.

\subsection{Microbiologic Changes to the Fe(III) Oxide Fraction}

The organisms primarily responsible for dissimilatory $\mathrm{Mn}$ and $\mathrm{Fe}$ reduction in the Bemidji aquifer appear to be species of Geobacter (Rooney-Varga et al., 1999) and Geothrix (Anderson et al., 1998; Coates et al., 1999). Geobacter readily utilizes poorly crystalline $\mathrm{Fe}(\mathrm{III})$ oxides as an electron acceptor through direct cellular contact, but has difficulty reducing crystalline Fe(III) oxides (Lovley and Phillips, 1988; Lovley et al., 1991; Nevin and Lovley, 2000). Geothrix, in contrast appears to liberate a soluble extracellular organic compound that aids electron transport from the cell to the oxide surface (Nevin and Lovley, 2002).

Our initial intent was to identify biologic changes to the $\mathrm{Fe}(\mathrm{III})$ mineralogy by direct comparisons of the pristine and contaminated sediments. However, quantitative comparisons between the pristine and contaminated sediments were not possible because of textural differences between the sediments. The pristine sediments were available in greater volume and this allowed us to develop a detailed model of the identity and size class distribution of the Fe(III) oxides by studying different particle-size fractions. The facies problem prevented us from concluding whether the absence of the hematite/goethite nodules in the contaminated zones (Table 5) was a result of iron-reducing microbiologic activity, or simply that the nodules were not there in the first place. We believe the latter explanation is more logical because high crystallinity and low surface area and porosity would have rendered the nodules recalcitrant to biologic reduction.

Valid comparisons, however, were possible between the source area and $\mathrm{Fe}(\mathrm{III})$ reducing zone sediments as these were of comparable texture. Significant differences in Fe(III) oxide mineralogy existed between the source and Fe(III) reducing sediments (Table 5). The Fe(III) reducing zone sediments contained disseminated goethite and hematite $\left(16 \%\right.$ of $\mathrm{Fe}_{\mathrm{TOT}}$, Table 3), and authigenic, fine-grained, disordered Fe(III) oxide visible in the central doublet of the Mössbauer spectra (26\% of $\mathrm{Fe}_{\text {TOT }}$, Table 3). Methanogenic conditions prevail in the source 
a.)

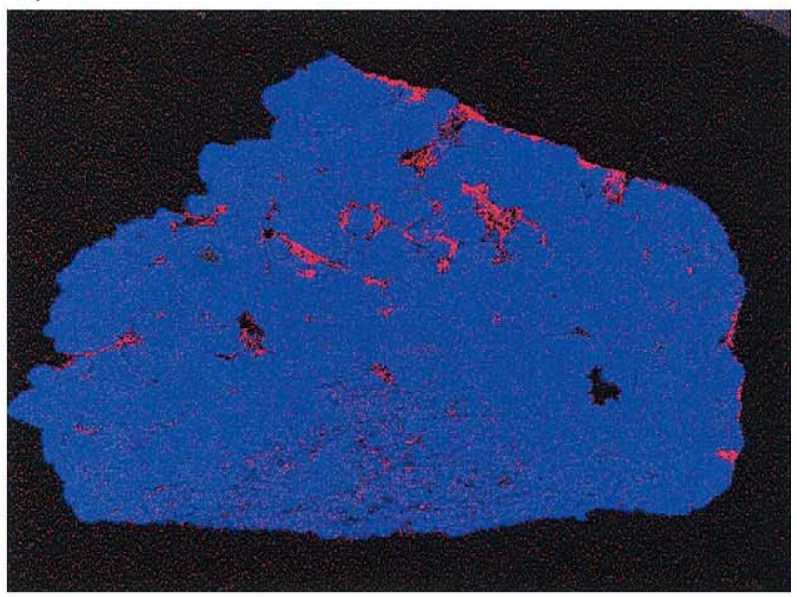

b.)

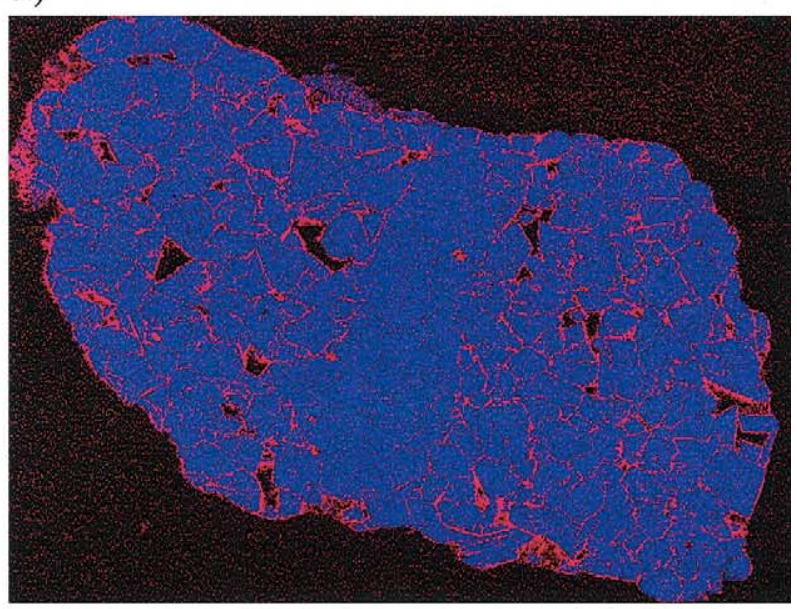

c.)

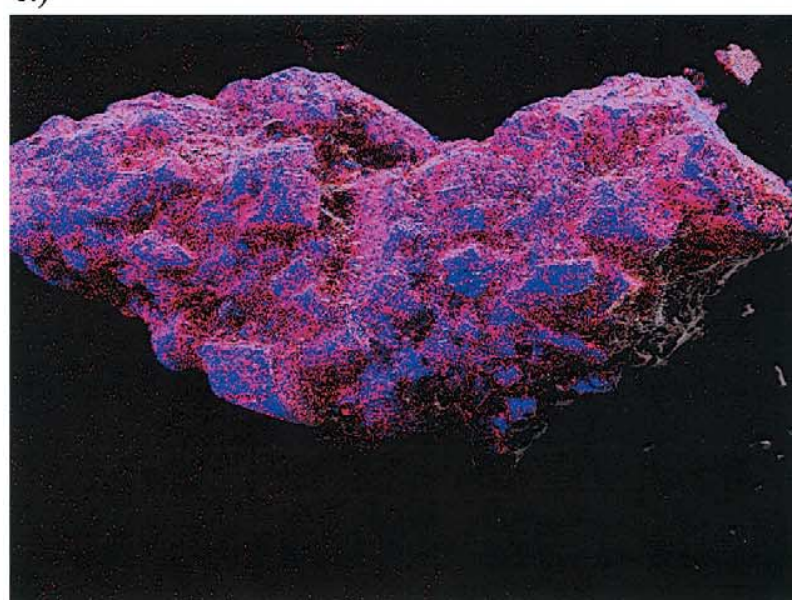

Fig. 14. EDS elemental distribution maps of $\mathrm{Ca}$ (blue) and $\mathrm{Fe}$ (red) in pristine and source zone carbonates. (a) Cross-sectioned particle from pristine sediment. (b) Cross-sectioned particle from source zone sediment. (c) Plan-view particle from source zone sediment.

zone sediments that were reported to have been depleted in bioavailable $\mathrm{Fe}(\mathrm{III})$ oxide needed to support Fe respiration (Anderson and Lovley, 1999). Accordingly, our analyses of the source area sediments defined the Fe(III) oxide fraction that
Table 5. Biogeochemical changes to Fe(III) oxide mineralogy.

\begin{tabular}{|c|c|c|c|c|c|}
\hline \multicolumn{2}{|l|}{ Pristine $(<2.0 \mathrm{~mm})$} & \multicolumn{2}{|c|}{ Fe(III)-reducing } & \multicolumn{2}{|l|}{ Source } \\
\hline $\begin{array}{l}\text { Hematite/goethite nodules } \\
\text { (sextet at } 77 \mathrm{~K}) \text { minor } \\
\text { component }\end{array}$ & & Absent & & Absent & \\
\hline $\left.\begin{array}{l}\text { Goethite/hematite coatings } \\
(\text { sextet at } 77 \mathrm{~K}) \text { major } \\
\text { component }\end{array}\right\}$ & $19 \%$ & Present & $16 \%$ & Absent & \\
\hline $\begin{array}{l}\text { Disordered goethite } \\
\text { (doublet at } 77 \mathrm{~K}, \mathrm{AOx} \\
\text { resistant) }\end{array}$ & & Present & $26 \%$ & & \\
\hline $\begin{array}{l}\text { Poorly crystalline } \mathrm{Fe}(\mathrm{III}) \text { oxic } \\
\text { (doublet at } 77 \mathrm{~K}, \mathrm{AOx} \\
\text { extractable) }\end{array}$ & & Present & & Present & $7 \%$ \\
\hline
\end{tabular}

More Reducing

could not be accessed by DIRB as an electron acceptor. The Mössbauer analyses, which, in turn, were consistent with the chemical extraction data (Table 1), showed the source area sediments were completely depleted in dispersed goethite/hematite, and partially depleted (to 7\%) in the authigenic, disordered Fe(III) phase (Table 5). The greatest mass percent change in $\mathrm{Fe}$ (III) oxide occurred in the authigenic phase that was reduced in concentration from 26 to $7 \%$ of $\mathrm{Fe}_{\text {Tот }}$ (Tables 2 and 3).

The analyses of the source and Fe(III) reducing sediments suggested two unexpected conclusions regarding the apparent bioavailability of $\mathrm{Fe}(\mathrm{III})$ oxides to DIRB (Table 5). First, all of the crystalline $\mathrm{Fe}(\mathrm{III})$ oxides that displayed a sextet in their 77 $\mathrm{K}$ spectra were depleted from the source sediment. Based on laboratory study (Lovley et al., 1991), crystalline Fe(III) oxides are believed to be poorly available to the Geobacter species that predominate the DIRB in the $\mathrm{Fe}(\mathrm{III})$ reducing zone (Rooney-Varga et al., 1999). The apparent absence of crystalline phases here indicates that the Bemidji DIRB can access these phases over the time span and under the in-situ conditions presented or, alternatively, that an abiotic reductive dissolution process such as organic acids in combination with $\mathrm{Fe}$ (II) (Hering and Stumm, 1990) was operative. Organic analyses of groundwater from the contaminated plume (Eganhouse et al., 1993; Cozzarelli et al., 1994) has indicated the presence of a wide range of organic acids resulting from the microbiologic transformation of aromatic hydrocarbons under anoxic conditions. Second, a significant residual concentration of the disordered, authigenic Fe(III) oxide was found in the source sediment ( $7 \%$ of $\mathrm{Fe}_{\mathrm{TOT}}$ by Mössbauer spectroscopy; $13.0 \%$ by DCB extraction, Table 1). This material was predominantly AOx soluble (Table 1), indicating that it was the most bioavailable of all the $\mathrm{Fe}$ (III) oxides present in the pristine sediment. Its lingering presence can only be attributed to physical inaccessibility. Perhaps this ferrihydrite exists as a weathering product within the interstices of igneous and mafic rock fragments, and is blocked from the aqueous phase by lack of continuous pore channels with size below those negotiable by micron-sized DIRB. The persistence of this more-soluble Fe(III) oxide phase in the source sediment argues against the widespread occurrence of solute-promoted abiotic (e.g., by organic acids as mentioned above) or biotic (e.g., by Geothrix) reductive dissolution as soluble reductants should have access, albeit masstransfer limited, to lithic fragment interiors. 


\subsection{Authigenic Mineral Phases}

Previous mineralogic studies of sediments from the anoxic plume have suggested that magnetite and ferroan calcite were authigenic (Baedecker et al., 1992). Mass balance geochemical modeling (Baedecker et al., 1993) implied the precipitation of siderite $\left(\mathrm{FeCO}_{3}\right)$ because groundwater within the anoxic plume was supersaturated with this phase, and down gradient $\mathrm{Fe}(\mathrm{II})_{\mathrm{aq}}$ concentrations decreased significantly before the onset of oxidation. Here we observed little definitive evidence for authigenic $\mathrm{Fe}$ (II) mineral formation. We did note that significant concentrations of $\mathrm{Fe}(\mathrm{II})_{\mathrm{aq}}$ could be displaced from the anoxic zone sediments with electrolyte, indicating an ion exchangeable $\mathrm{Fe}(\mathrm{II})$ fraction in the sediment. Ion exchange was not included in the geochemical modeling of Baedecker et al. (1993), possibly over estimating the importance of siderite or ferroan calcite as the only attenuation mechanism to achieve mass balance.

Small concentrations of magnetite were common to both the pristine and contaminated aquifer sediments. This magnetite, like that observed by Baedecker et al. (1992) exhibited euhedral morphology characteristic of magmatic or metamorphic origin. This magnetite was, consequently, considered detrital. We saw no magnetite with size and morphology characteristic of topotactic biologic formation from ferrihydrite (e.g., Fredrickson et al., 1998; Zachara et al., 2002).

SEM/EDS analyses of carbonates from the pristine and anoxic plume regions showed that a ferroan calcite/siderite grain cement was common to the interiors of the detrital carbonates. Carbonates from the pristine sediment had discontinuous surface accumulations of Fe (Figs. 12 and 14); however those from the source area were veneered with a nearly continuous layer of Fe-calcite precipitate (Fig. 14). These observations provide tentative support that siderite or Fe-calcite precipitation were plausible reactions, amongst others, reducing down gradient $\mathrm{Fe}(\mathrm{II})_{\mathrm{aq}}$ concentrations in the anoxic plume.

\section{CONCLUSIONS}

Significant differences in the mass content and identity of $\mathrm{Fe}$ (III) oxides were noted between the pristine Bemidji aquifer sediment and those sampled from the anoxic plume where DIRB activity was ongoing [Fe(III)-reducing zone] or had ceased due to depletion of bioavailable Fe(III) (source sediments). The source area sediment was more depleted in Fe(III) oxide phases than were the $\mathrm{Fe}$ (III) reducing zone sediments. Modeling of the Mössbauer spectral areas indicated that poorly crystalline $\mathrm{Fe}(\mathrm{III})$ oxide, goethite, and hematite were depleted in the source area sediments through biologic and/or associated chemical activity. A fraction of the potentially bioavailable, AOx-extractible ferrihydrite, however, remained in the source sediment and apparently was not bioavailable even under the highly reducing conditions found in this sample. Because oxide coatings were no longer visible by optical microscopy on source area mineral grains or lithic fragments, it was concluded that residual ferrihydrite existed in intergrain pores or fractures in lithic fragments with restricted accessibility.

In contrast to the source area sediment, goethite and hematite were not depleted in the Fe(III)-reducing contaminated sediment. However, poorly crystalline Fe(III) oxide was lower, when referenced to other phases, than observed in the pristine sample, signifying its partial dissolution by biologic and/or chemical processes. In both reduced sediments, a proportionate increase in the mass fraction of clinochlore occurred concomitant with the loss of reducible Fe(III) oxides. Fe(III) associated with epidote or other silicates was not affected by microbial reduction in either of the anoxic plume sediments.

The large indigenous $\mathrm{Fe}$ (II) fraction made it difficult to determine, by Mössbauer spectroscopy, whether small concentrations of authigenic ferrous minerals had formed in the anoxic plume from DIRB activity. However, we saw no other evidence for biogenic magnetite or green rust formation. Relatively thick particle coatings of an Fe-containing phase imaged by SEM/ EDS on carbonate lithic fragments from the source zone provided presumptive evidence for the precipitation of ferroan calcite in regions of the aquifer with elevated $\mathrm{Fe}(\mathrm{II})_{\mathrm{aq}}$ resulting from DIRB activity.

Acknowledgments-This research was supported by the Chemical Sciences Division (Geosciences Program), Basic Energy Sciences (BES), U.S. Department of Energy (DOE). Mössbauer, X-ray diffraction, and electron microscopic analyses were performed at the W.R. Wiley Environmental and Molecular Sciences Laboratory (EMSL), a national scientific user facility sponsored by DOE's Office of Biological and Environmental Research (OBER) and located at the Pacific Northwest National Laboratory (PNNL). PNNL is operated for the Department of Energy by Battelle. We thank Jeremy Fein for his review of the manuscript and Jim S. Young of PNNL/EMSL for his SEM/EDS analyses of the carbonate lithic fragments.

Associate editor: J. Fein

\section{REFERENCES}

Anderson R. T., Rooney-Varga J. N., Gaw C. V., and Lovley D. R. (1998) Anaerobic benzene oxidation in the $\mathrm{Fe}(\mathrm{III})$ reduction zone of petroleum-contaminated aquifers. Environ. Sci. Technol. 32, 1222 1229.

Anderson R. T. and Lovley D. R. (1999) Naphthalene and benzene degradation under $\mathrm{Fe}$ (III)-reducing conditions in petroleum-contaminated aquifers. Bioremediation J. 3, 121-135.

Baedecker M. J., Cozzarelli I. M., Evans J. R., and Hearn P. P. (1992) Authigenic mineral formation in aquifers rich in organic material. In Water-Rock Interaction (eds. Y. K. Kharaka and A. S. Maest), pp. 257-261. Balkema.

Baedecker M. J., Cozzarelli I. M., Eganhouse R. P., Siegel D. I., and Bennett P. C. (1993) Crude oil in a shallow sand and gravel aquifer-III. Biogeochemical reactions and mass balance modeling in anoxic groundwater. Appl. Geochem. 8, 569-586.

Bancroft G. M., Maddock A. G., and Burns R. G. (1967) Applications of the Mössbauer effect to silicate mineralogy, I. Iron silicates of known crystal structures. Geochim. Cosmochim. Acta 31, 22192246.

Bennett P. C., Siegel D. E., Baedecker M. J., and Hult M. F. (1993) Crude oil in a shallow sand and gravel aquifer-I. Hydrogeology and inorganic geochemistry. Appl. Geochem. 8, 529-549.

Coates J. D., Ellis D. J., Gaw C. V., and Lovley D. R. (1999) Geothrix fermentens gen. nov. sp. nov., an acetate-oxidizing $\mathrm{Fe}(\mathrm{III})$ reducer capable of growth via fermentation. Int. J. Syst. Bacteriol. 49, 1615-1622.

Cozzarelli I. M., Baedecker M. J., Eganhouse R. P., and Goerlitz D. F. (1994) The geochemical evolution of low-molecular-weight organic acids derived from the degradation of petroleum contaminants in groundwater. Geochim. Cosmochim. Acta 58, 863-877.

Eganhouse R. P., Baedecker M. J., Cozzarelli I. M., Aiken G. R., Thorn K. A., and Dorsey T. F. (1993) Crude oil in a shallow sand and gravel aquifer-II. Organic geochemistry. Appl. Geochem. 8, 551567. 
Fredrickson J. K., Zachara J. M., Kennedy D. W., Dong H., Onstott T. C., Hinman N. W., and Li S.-M. (1998) Biogenic iron mineralization accompanying the dissimilatory reduction of hydrous ferric oxide by a groundwater bacterium. Geochim. Cosmochim. Acta $\mathbf{6 2}$, 3239-3257.

Fredrickson J. K., Kota S., Kukkadapu R. K., Liu C., and Zachara J. M. (2003) Influence of electron donor/acceptor concentrations on hydrous ferric oxide (HFO) bioreduction. Biodegradation 14, 91-103.

Fysh S. A. and Clark P. E. (1982) Aluminous hematite: A Mössbauer study. Phys. Chem. Miner. 8, 257-267.

Hering J. G. and Stumm W. (1990) Oxidative and reductive dissolution of minerals. In Mineral-Water Interface Geochemistry (eds. M. F. Hochella, Jr. and A. F. White), pp. 427-465. Mineralogical Society of America.

Janot C., Chabanel H., and Herzog E. (1973) E'tude d'une limonite par effect Mössbauer. Bull. Soc. Franc. Miner. Cristl. 91, 166-176.

Kukkadapu R. K., Zachara J. M., Smith S. C., Fredrickson J. K., and Liu C. L. (2001) Dissimilatory bacterial reduction of Al-substituted goethite in subsurface sediments. Geochim. Cosmochim. Acta 65, 2913-2924.

Kukkadapu R. K., Zachara J. M., Fredrickson J. K., Smith S. C., Dohnalkova A. C., and Russell C. K. (2003) Transformation of 2-line ferrihydrite to 6-line ferrihydrite under oxic and anoxic conditions. Am. Mineral. 88:1903-1914.

Kukkadapu R. K., Zachara J. M., Fredrickson J. K., and Kennedy D. W. (2004) Biotransformation of synthetic 2-line silica-ferrihydrite coprecipitates by a dissimilatory Fe(III)-reducing bacterium. Formation of carbonate green rust in the presence of phosphate. Geochim. Cosmochim. Acta, in press.

Lovley D. R. (1990) Magnetite formation during microbial dissimilatory iron reduction. In Iron Biominerals (eds. R. B. Frankel and R. P. Blakemore), pp. 151-166. Plenum Press.

Lovley D. R. and Phillips E. J. P. (1986) Availability of ferric iron for microbial reduction in bottom sediments of the freshwater tidal Potomac River. Appl. Environ. Microbiol. 52, 751-757.

Lovley D. R. and Phillips E. J. P. (1988) Novel mode of microbial energy metabolism: Organic carbon oxidation coupled to dissimilatory reduction of iron or manganese. Appl. Environ. Microbiol. 54, $1472-1480$

Lovley D. R., Baedecker M. J., Lonergan D. J., Cozzarelli I. M., Phillips E. J. P., and Siegel D. I. (1989) Oxidation of aromatic contaminants coupled to microbial iron reduction. Nature 339, 297 299.

Lovley D. R., Phillips E. J. P., and Lonergan D. J. (1991) Enzymatic versus nonenzymatic mechanisms for $\mathrm{Fe}(\mathrm{III})$ reduction in aquatic sediments. Environ. Sci. Technol. 25, 1062-1067.

Mehra O. P. and Jackson M. L. (1960) Iron oxide removal from soils and clays by a dithionite-citrate system buffered with sodium bicarbonate. Clays Clay Miner. 7, 317-327.
Mortimer R. J. G. and Coleman M. L. (1997) Microbial influence on the isotopic composition of diagenetic siderite. Geochim. Cosmochim. Acta 61, 1705-1711.

Murad E. (1988) Properties and behavior of iron oxides as determined by Mössbauer spectroscopy. In Iron in Soils and Clay Minerals (eds. J. W. Stucki, B. A. Goodman, and U. Schwertmann), pp. 309-350. Reidel.

Nevin K. P. and Lovley D. R. (2000) Lack of production of electronshuttling compounds or solubilization of $\mathrm{Fe}(\mathrm{III})$ during reduction of insoluble Fe(III) oxide by Geobacter metallireducens. App. Environ. Microbiol. 66, 2248-2251.

Nevin K. P. and Lovley D. R. (2002) Mechanisms for accessing insoluble $\mathrm{Fe}(\mathrm{III})$ oxide during dissimilatory $\mathrm{Fe}(\mathrm{III})$ reduction by Geothrix fermentans. Appl. Environ. Microbiol. 68, 2294-2299.

Nielson K. K. (1978) Application of direct peak analysis to energydispersive X-ray fluorescence spectra. X-ray Spect. 7, 15-22.

Nielson K. K. and Sanders R. W. (1982) The SAP3 computer program for quantitative multi-element analysis by energy-dispersive $\mathrm{X}$-ray fluorescence. Report No. PNL-4713, Pacific Northwest National Laboratory Report to U.S. Department of Energy, pp. 43-50.

Ono K. and Ito A. (1964) Mössbauer study of magnetic properties in ferrous compounds. J. Phys. Chem. 19, 899-907.

Rancourt D. G. and Ping J. Y. (1991) Voigt-based methods for arbitrary-shape static hyperfine parameter distributions in Mössbauer spectroscopy. Nucl. Instrum. Meth. Phy. Res. B58, 85-87.

Rooney-Varga J. N., Anderson R. T., Fraga J. L., Ringelberg D., and Lovley D. R. (1999) Microbial communities associated with anaerobic benzene degradation in a petroleum-contaminated aquifer. Appl. Environ. Microbiol. 65, 3056-3063.

Sparks N. H. C., Mann S., Bazylinski D. A., Lovley D. R., Jannasch H. W., and Frankel R. B. (1990) Structure and morphology of magnetite anaerobically-produced by a marine magnetotactic bacterium and a dissimilatory iron reducing bacterium. Earth Planet. Sci. Lett. 98, 14-22.

Stookey L. L. (1970) Ferrozine-A new spectrophotometric reagent for iron. Anal. Chem. 42, 779-781.

Suttill R. J., Turner P., and Vaughan J. (1982) The geochemistry of iron in recent tidal-flat sediments of the Wash area, England: A mineralogical, Mössbauer, and magnetic study. Geochim. Cosmochim. Acta 46, 205-217.

Vandenberghe R. E., De Grave E., Landuydt C., and Bowen L. H. (1990) Some aspects concerning the characterization of iron oxides and hydroxides in soils and clays. Hyperfine Interactions 53, 175196.

Zachara J. M., Kukkadapu R. K., Fredrickson J. K., Gorby Y. A., and Smith S. C. (2002) Biomineralization of poorly crystalline $\mathrm{Fe}(\mathrm{III})$ oxides by dissimilatory metal reducing bacteria (DMRB). Geomicrobiol. J. 19, 179-207. 